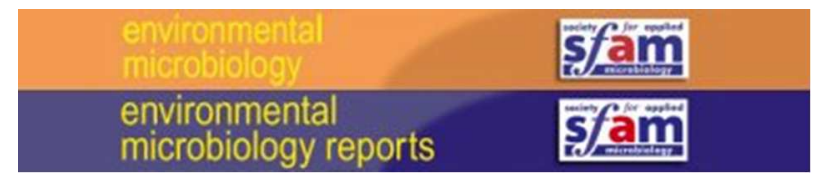

\title{
Microbial network, phylogenetic diversity and community membership in the active layer across a permafrost thaw gradient
}

\begin{tabular}{|c|c|}
\hline Journal: & Environmental Microbiology and Environmental Microbiology Reports \\
\hline Manuscript ID & Draft \\
\hline Journal: & Environmental Microbiology \\
\hline Manuscript Type: & EMI - Research article \\
\hline Date Submitted by the Author: & $\mathrm{n} / \mathrm{a}$ \\
\hline Complete List of Authors: & $\begin{array}{l}\text { Mondav, Rhiannon; Uppsala University, Ecology and Genetics, Limnology; } \\
\text { University of Queensland, Chemistry and Molecular Biosciences } \\
\text { McCalley, Carmody; Rochester Institute of Technology, Thomas H. Gosnell } \\
\text { School of Life Sciences; University of New Hampshire, Earth Systems } \\
\text { Research Center } \\
\text { Hodgkins, Suzanne; Florida State University, Department of Earth Ocean } \\
\text { and Atmospheric Science } \\
\text { Frolking, Steve; University of New Hampshire, Institute for the Study of } \\
\text { Earth, Oceans, and Space } \\
\text { Saleska, Scott; University of Arizona, Ecology and Evolutionary Biology } \\
\text { Rich, Virginia; University of Arizona, Department of Soil, Water and } \\
\text { Environmental Science; Ohio State University, Microbiology Department } \\
\text { Chanton, Jeff; Florida State University, Department of Earth Ocean and } \\
\text { Atmospheric Science } \\
\text { Crill, Patrick; Stockholm University, Department of Geological Sciences }\end{array}$ \\
\hline Keywords: & $\begin{array}{l}\text { microbial ecology, microbially-influenced global change, environmental } \\
\text { signal/stress responses, microbial communities }\end{array}$ \\
\hline
\end{tabular}


1 Microbial network, phylogenetic diversity and community membership in the

\section{2 active layer across a permafrost thaw gradient}

3 Authors:

4 Rhiannon Mondav ${ }^{1,2^{\star}}$, Carmody $\mathrm{K} \mathrm{McCalley}{ }^{3,4,+}$, Suzanne B Hodgkins ${ }^{5}$, Steve

5 Frolking $^{4}$, Scott R Saleska $^{3}$, Virginia I Rich ${ }^{6, \wedge}$, Jeff P Chanton $^{5}$, Patrick M Crill $^{7}$

6 Affiliations:

71 Department of Ecology and Genetics, Limnology, Uppsala University, Uppsala

8 75236, Sweden

92 School of Chemistry and Molecular Biosciences, University of Queensland,

10 Brisbane 4072, Australia

$11^{3}$ Department of Ecology and Evolutionary Biology, University of Arizona, Tucson

1285721 , USA

$13^{4}$ Institute for the Study of Earth, Oceans, and Space, University of New Hampshire,

14 Durham NH 03824, USA

$15{ }^{5}$ Department of Earth Ocean and Atmospheric Science, Florida State University,

16 Tallahassee 32306-4320, USA

$17^{6}$ Department of Soil, Water and Environmental Science, University of Arizona,

18 Tucson 85721, USA

$19{ }^{7}$ Department of Geology and Geochemistry, Stockholm University, Stockholm 10691,

20 Sweden

$21{ }^{*}$ Corresponding author:

22 RMondav, Norbyvagen, Uppsala University, Uppsala, SE75236 Sweden, +46 (0)7

232731 7286, rhiannon.mondav@ebc.uu.se

24 Running Title: Microbial community across a permafrost thaw gradient

26 Current addresses: ${ }^{+}$Thomas H. Gosnell School of Life Sciences, Rochester Institute

27 of Technology, Rochester, New York 14623, USA; ^ Department of Microbiology, The

28 Ohio State University, Columbus 43210, USA. 


\section{Summary}

30 Biogenic production and release of methane $\left(\mathrm{CH}_{4}\right)$ from thawing permafrost has the

31 potential to be a strong source of radiative forcing. We investigated changes in the

32 active layer microbial community of three sites representative of distinct permafrost

33 thaw stages at a palsa mire in northern Sweden. The palsa sites with intact

34 permafrost, and low radiative forcing signature had a phylogenetically clustered

35 community dominated by Acidobacteria and Proteobacteria. The bog with thawing

36 permafrost and low radiative forcing signature was dominated by hydrogenotrophic

37 methanogens and Acidobacteria, had lower alpha diversity, and midrange

38 phylogenetic clustering, characteristic of ecosystem disturbance affecting habitat

39 filtering, shifting from palsa-like to fen-like at the waterline. The fen had no underlying

40 permafrost, and the highest alpha, beta and phylogenetic diversity, was dominated

41 by Proteobacteria and Euryarchaeota, and was significantly enriched in

42 methanogens. The mire microbial network was modular with module cores

43 consisting of clusters of Acidobacteria, Euryarchaeota, or Xanthomonodales. Loss of

44 underlying permafrost with associated hydrological shifts correlated to changes in

45 microbial composition, alpha, beta, and phylogenetic diversity associated with a

46 higher radiative forcing signature. These results support the complex role of

47 microbial interactions in mediating carbon budget changes and climate feedback in

48 response to climate forcing.

\section{Introduction}

51 Modern discontinuous permafrost is found in regions with a mean annual air

52 temperature between $-5{ }^{\circ} \mathrm{C}$ and $+2{ }^{\circ} \mathrm{C}$ and where the insulating properties of peat

53 enable persistence of permafrost above freezing temperatures (Shur and Jorgenson,

54 2007; Seppälä, 2011). As these regions experience climate change-induced

55 warming, they are approaching temperatures that are destabilizing permafrost

56 (Schuur et al., 2015). Permafrost degradation typically leads to significant loss of soil Wiley-Blackwell and Society for Applied Microbiology 
57 carbon (C) through erosion, fire and microbial mineralisation (Osterkamp et al., 2009;

58 Mack et al., 2011). The area of permafrost at risk of thaw in the next century has

59 been estimated to be between $10^{6}$ and $10^{7} \mathrm{~km}^{2}$, with the quantity of $\mathrm{C}$ potentially lost

60 ranging from $1-4 \times 10^{14} \mathrm{~kg}$ (McGuire et al., 2010; Schuur et al., 2015). Increasing

61 plant production in thawed systems may partially compensate for this loss but this is

62 poorly defined (Hicks Pries et al., 2013). Thus, the potential positive feedbacks to

63 climate change are not well constrained, and will vary depending on the emission

64 ratio of the greenhouse gases (GHGs) carbon dioxide $\left(\mathrm{CO}_{2}\right)$ and methane $\left(\mathrm{CH}_{4}\right)$, and

65 the time scale considered (Dorrepaal et al., 2009; Nazaries et al., 2013). Changes in

66 microbial community membership (e.g. methanogen to methanotroph ratio) will be a

67 significant factor controlling the $\mathrm{CO}_{2}$ to $\mathrm{CH}_{4}$ emission ratio (Hodgkins et al., 2014).

68 To examine the relationship between permafrost thaw, shifting GHG emissions, and

69 the microbial community, we investigated a natural in situ thaw gradient at Stordalen

70 Mire, northern Sweden, on the margin of the discontinuous permafrost zone.

71 Permafrost thaw has been causatively linked to changes in topography, vegetation,

72 and GHG emission at Stordalen (Christensen, 2004; Johansson et al., 2006;

73 Bäckstrand et al., 2008, 2010; Johansson and Åkerman, 2008), and elsewhere

74 (Turetsky et al., 2007; Olefeldt et al., 2013). Currently, the Mire is a partially

75 degraded complex of elevated, drained hummocks (palsas with intact permafrost)

76 and wet depressions (bogs with thinning permafrost and fens without any

77 permanently frozen ground), each representing different stages of thaw (Fig S1), and

78 each characterised by distinct vegetation (Bhiry and Robert, 2006; Johansson et al.,

79 2006). Changes in topography and vegetation (proxy for thaw) have been tracked

80 through the last 40 years and show a decrease in area covered by palsa, an

81 expansion of fens and a variable area covered by bogs (Christensen et al., 2004;

82 Malmer et al., 2005; Johansson et al., 2006). Part of the known palsa-cycle is the

83 external carving and internal collapse of palsas into the surrounding bog or fen,

84 though the time scale at which this happens varies depending on whether dome- 
bioRxiv preprint doi: https://doi org/10 1101/143578; this version posted May 29, 2017. The copyright holder for this preprint (which was not aCC-BY-NC-ND 4.0 International license.

85 palsas or palsa-complexes/plateaus (as seen at Stordalen) are considered (Railton

86 and Sparling, 1973; Zoltai, 1993; Sollid and Sørbel, 1998; Gurney, 2001; Turetsky et

87 al., 2007; Seppälä, 2011; O’Donnell et al., 2012; Liebner et al., 2015). At Stordalen

88 complete collapse due to absence of permafrost results in a fen or lake, while partial

89 collapse due to permafrost thinning results in a bog (Johansson et al., 2006).

90 Photographs, topographical survey and GHG data comparing Stordalen in the 1970's

91 and 1980's to 2000's and 2010's show that for the particular area studied here the

92 palsa has degraded both externally and internally (Fig S1, S2). Bogs (sphagnum or

93 semi-wet) have expanded within the perimeter of the palsa-complex and around its

94 southern edge, while fens (eriophorum, wet, or tall-graminoid) have encroached from

95 the north, east, and west having converted the bog that once existed on the western

96 and eastern edges of the palsa, along with increases in GHG emissions (Rydén et

97 al., 1980; Malmer et al., 2005; Johansson et al., 2006; Bäckstrand et al., 2010). The

98 majority of bog samples were taken from the subsided section within the palsa-

99 complex, while the fen samples were taken from the western side of the complex,

100 which was recorded as a bog 40 years ago. As permafrost continues to disappear

101 from Stordalen over the coming decades, subsidence of the surface will likely

102 increase, driving the creation of more transient bog-type communities and

103 degradation into fens (Christensen, 2004; Parviainen and Luoto, 2007; Johansson

104 and Åkerman, 2008; Fronzek et al., 2010; Bosiö et al., 2012; Jones et al., 2016). It is

105 also predicted that this region could be free of permafrost as early as 2050

106 (Parviainen and Luoto, 2007; Fronzek et al., 2010). The "natural experiment"

107 underway in the Mire presents a model ecosystem for investigating climate-driven

108 changes in lowland permafrost regions with high cryosequestered-C (Masing et al.,

109 2009).

110 As a model system, the Mire has been intensively studied over the last several

111 decades for permafrost thaw impacts on plant communities, hydrology, and

112 biogeochemistry - providing rich context for interpreting microbial communities. The Wiley-Blackwell and Society for Applied Microbiology 
113 seasonally thawed peat layer (active layer) of Stordalen's palsas is drained, aerobic,

114 ombrotrophic (rain-fed) and isolated from nutrient-rich groundwater. The palsa sites'

115 low plant productivity and aerobic decomposition make them net emitters of

116 appreciable $\mathrm{CO}_{2}$ and no $\mathrm{CH}_{4}$, with a net $\mathrm{C}$ balance $(\mathrm{NCB})$ of $-30 \mathrm{mgC} / \mathrm{m}^{2} /$ day

117 (negative value indicates net $\mathrm{C}$ emissions, positive indicates net uptake; Bäckstrand

118 et al., 2010). In contrast, the bog sites (semi-wet in Johansson et al 2006) are

119 physically lower and collect rainwater, leading to partial inundation, and are

120 dominated by layered bryophytes (typically Sphagnum spp.). Although this results in

121 less lignin (a recalcitrant $\mathrm{C}$ compound not produced by sphagnum), $\mathrm{C}$ degradation is

122 still slow due to sphagnum's higher phenolic content (Freeman et al., 2004) and

123 extremely poor C:N ratios of up to 70:1 (Hodgkins et al., 2014). Partially anoxic

124 conditions permit microbial fermentation and $\mathrm{CH}_{4}$ production (Nilsson and Bohlin,

125 1993; Hobbie et al., 2000). Mire bog sites have the lowest radiative forcing signature

126 ( $\mathrm{NCB}$ in $\mathrm{CO}_{2}$ eq. of $-8 \mathrm{mgC} / \mathrm{m}^{2} /$ day; Bäckstrand et al., 2010), as fixation of $\mathrm{C}$ in the

127 bog peat is high compared to emission of $C$ gases. Finally, the fully-thawed fen sites

128 (tall-graminoid in Johansson et al 2006) are the most subsided and are

129 minerotrophic (groundwater-fed). Vegetation succession results in dominance of

130 graminoids (sedges, rushes, reeds), with a subsequent shift in the litter preserved as

131 peat. Some graminoids enhance gas transport between inundated soil and the

132 atmosphere (Chanton et al., 1993) and due to high productivity, contribute

133 appreciable fresh labile organic litter and exudates (Wagner and Liebner, 2009). High

134 productivity results in the fens being the Mire's biggest gross C-sinks of the Mire,

135 however their high $\mathrm{CH}_{4}$ emissions result in a net warming potential 7 and 26 times

136 greater than the palsa and bog respectively (NCB in $\mathrm{CO}_{2}$ eq. of $-213 \mathrm{mgC} / \mathrm{m}^{2} /$ day,

137 Bäckstrand et al., 2010; Christensen et al., 2012).

138 Here we explore the relationship between the biogeochemical differences among 139 palsa, bog, and fen and the active layer microbial community, via a temporal (over a

140 growing season) and spatial (across habitats, and with depth through the active Wiley-Blackwell and Society for Applied Microbiology 
bioRxiv preprint doi: https://doi.org/10.1101/143578; this version posted May 29, 2017. The copyright holder for this preprint (which was not

141 layer) community survey using SSU rRNA gene amplicon sequencing, pore-water

142 chemistry, peat chemistry, stable $\mathrm{C}$ isotope analyses, and $\mathrm{CH}_{4}$ flux. Previous work

143 has demonstrated that permafrost thaw has an overall impact on Stordalen Mire's

144 microbiota (Mondav \& Woodcroft et al, 2014; Hodgkins et al., 2014; McCalley et al.,

145 2014). Here, we deepen understanding of this impact by addressing the following

146 descriptors with respect to climate-induced thaw and correlated environmental

147 parameters: 1) dominant phyla, 2) beta diversity, 3) assemblage alpha diversity, 4)

148 phylogenetic distance to identify drivers of assembly processes, 5) community

149 network, and 6) C-cycling phylotype distribution.

\section{Results and discussion}

152 Dominant phyla of each thaw stage

153 Dominant phyla can inform on geochemical correlations and community functionality,

154 reflecting overall habitat conditions. Acidobacteria and Proteobacteria were

155 ubiquitous phyla across the Mire (Fig 1). Dominant palsa phyla also included

156 Actinobacteria and Candidate bacterial phylum "WD272" (WPS-2), the abundances

157 of which decreased across the thaw gradient (palsa>bog>fen). Surface bog samples

158 had similar community composition to palsa samples being dominated by

159 Acidobacteria and Proteobacteria suggesting that site classification, which was

160 identified by vegetation, is not the only environmental correlate important to microbial

161 community assembly in the Mire. Bog samples at or below the waterline (midpoint

162 and deepest) retained similar proportions of Acidobacteria and Actinobacteria as

163 palsa samples. Proteobacteria however, were relatively less abundant, likely due to

164 lower C lability (Goberna et al., 2014; Hodgkins et al., 2014), and were replaced by

165 Euryarchaeota in deeper anoxic samples. The shift in phylum ratios from palsa-like

166 to fen-like supports the transitional nature of this thawing site. The most abundant

167 phyla in the fen were Euryarchaeota, Proteobacteria, Bacteroidetes, and Chloroflexi 
168 followed by Acidobacteria. Woesearchaeota (DHVEG-6) were only detected in fen

169 samples.

$170<$ Fig 1, $110 \mathrm{~mm}$ wide>

171 Beta diversity and environmental correlates of site assemblages

172 Microbial assemblages were significantly different (anosim $\left.r^{2}{ }_{\text {adj }}=0.90, p<0.001\right)$ at

173 the sample OTU level between sites. Whole community analysis by nonmetric

174 multidimensional scaling (NMDS) $\left(\right.$ Fig $2 a$, stress $\left.=0.082, r^{2}=0.99\right)$ clustered

175 samples by site. Samples separated along the primary NMDS axis according to

176 hydrological states with ombrotrophic (palsa and bog) samples clustered together left

177 of the origin and the minerotrophic fen samples to the far right. The secondary axis

178 separated samples according to depth from surface with the two ombrotrophic site

179 samples diverging from each other with depth. The palsa and surface bog

180 assemblages overlapped at both OTU (Fig 2) and phyla level (Fig 1). Sharing of

181 species across the palsa and surface bog (aerobic ombrotrophic) is likely due to

182 local dispersal and seen in other methanogenic soils (Kim and Liesack, 2015). Local

183 dispersal mechanisms include transport by burrowing lemmings, palsa dome runoff

184 washing microbes into lower altitudes, local aerial dispersal (Bowers et al., 2011).

185 Ubiquitous deposition across the mire via precipitation may also contribute (Christner

186 et al., 2008). These more ubiquitous microbes likely persist through environmental

187 filtering including oxygenation, acidity, ombrotrophy, and bryophyte presence (Brettar

188 et al., 2011; King et al., 2012).

189 C-fixing autotrophs were associated with all samples except the deepest bog and

190 fen. Bacterial methanotrophs, while distributed across the Mire, were not associated

191 with deep fen or deep bog samples, supporting their known preference for aerobic

192 and microaerobic habitats. Both autotrophs and methanotrophs were unique to

193 individual sites with only a few OTUs shared across the surface bog and palsa

194 samples. The majority of methanogenic phylotypes were clustered exclusively with 
bioRxiv preprint doi: https://doi.org/10.1101/143578; this version posted May 29, 2017. The copyright holder for this preprint (which was not

certified by peer review) is the author/funder, who has granted bioRxiv a license to display the preprint in perpetuity. It is made available undeage $\mathbf{8}$ of $\mathbf{4 3}$ aCC-BY-NC-ND 4.0 International license.

195 fen samples, though a secondary cluster of methanogens while more tightly

196 associated to deep bog samples were detected across both bog and fen.

197 Relative increases in $\delta D_{\mathrm{H} 2 \mathrm{O}}$ and $\delta \mathrm{D}_{\mathrm{CH} 4}$ were correlated with palsa sample 198 assemblages (Fig 2a\&b). This is indicative of methanotrophy as supported both by

199 the detection of methanotrophic phylotypes but also by the negative $\mathrm{CH}_{4}$ flux (uptake

200 of $\mathrm{CH}_{4}$ from atmosphere) recorded by the palsa auto-chambers. Increased peat C:N

201 ratio, pore-water $\mathrm{C}: \mathrm{N}$, and porewater DOC were correlated with the bog 202 assemblages supporting previous studies finding higher DOC in run-off from 203 ombrotrophic regions of the Mire (Nilsson, 2006; Kokfelt et al., 2010) Pore-water N

204 content decreased in relation to deeper bog samples. Increased $\mathrm{pH}, \mathrm{CH}_{4}$ flux from 205 the auto-chambers, flux $\delta^{13} \mathrm{C}_{\mathrm{CH} 4}$ from the autochambers, pore-water $\delta^{13} \mathrm{C}_{\mathrm{CH} 4}$, and 206 water table depth (WTD) were positively correlated with fen samples (Fig 2a). Pore207 water $\mathrm{CH}_{4}$ concentration, pore-water $\mathrm{CO}_{2}$ concentration, $\mathrm{CO}_{2}$ gas from peat 208 samples, and pore-water total C increased with deeper (below watertable) bog and 209 fen samples. Increased $\mathrm{CH}_{4}$ in porewater and flux measurements were correlated to 210 presence of detected methanogens (Fig 2b) supporting established linkage between 211 detected abundance and metabolic activity of these microbes (Mondav et al., 2014).

\section{$212<$ Fig 2, $110 \mathrm{~mm}$ wide>}

\section{Microbial assemblage alpha diversity}

214 The number of unique OTUs per normalised $(N=2000)$ sample ranged from 309 in 215 the merged anoxic bog samples from august 2011 up to 1226 in the combined 216 surface fen samples from june 2011 (Fig 3), with a cross-Mire mean OTU richness of 217721 (s.d. 204 OTUs). The total richness was 9700 across the Mire for the 42 merged 218 and normalised samples. The percentage of OTUs that could not be taxonomically 219 classified either to or below order level was typical, at 40\%, supporting that 220 environmental microbes are still appreciably under-characterised. Total, archaeal, 221 and bacterial assemblage alpha diversity as measured by richness (observed 222 OTUs), Fisher alpha (Fisher et al., 1943), Shannon entropy (Shannon and Weaver, Wiley-Blackwell and Society for Applied Microbiology 
223 1949), and Heip's evenness (Heip et al., 1974) varied between thaw stages, with

224 there being a significant difference $(p<0.05)$ between sites as measured by Kruskal-

225 Wallace test (K-W) (Fig 3). For total assemblage alpha diversity the bog had lowest

226 (richness and fisher alpha), and was significantly lower than the palsa (shannons

227 entropy and heips evenness) K-W post-hoc test for significance (K-Wmc, $p<0.001)$.

228 The fen had highest archaeal alpha diversity (richness, fisher, and Shannon) while

229 the palsa had most even archaeal assemblage $(\mathrm{K}-\mathrm{Wmc}, \mathrm{p}<0.001)$. Apart from the

230 exception of archaeal evenness the bog had lower or lowest alpha diversity of the

231 three sites. Archaeal evenness in the bog site covers a wide range from

232 assemblages with high evenness similar to that found in palsa samples but also

233 includes assemblages that were more highly dominated than those found in the fen

234 (Fig 3). Evenness is an important property of methane producing communities where

235 higher evenness of fen assemblies, compared to bog samples, may constitute a

236 feedback mechanism by which higher $\mathrm{CH}_{4}$ production is enabled (Galand et al.,

237 2003; Godin et al., 2012). Depth of sample was related to decreases in all alpha

238 diversity metrics (total and bacterial, range: $-0.46<\rho<-0.36, p<0.01$ ). Bacterial

$239\left(r^{2}\right.$ adj $\left.=0.92, p<0.001\right)$ and total richness $\left(r^{2}\right.$ adj $\left.=0.92, p<0.001\right)$ decreased with depth

240 in the bog while Archaeal richness increased $\left(r^{2}\right.$ adj $\left.=0.69, p<0.001\right)$ (Fig 3, Equations

$241 \mathrm{~S} 1 \mathrm{a}-\mathrm{c}$ ). Higher DOC correlated to lower richness (total $\rho=-0.76$, bacterial $\rho=-0.70$,

242 and archaeal $\rho=-0.74: p<0.001$ ) (Fig S3). Bacterial richness was correlated to

243 decreased porewater $\mathrm{CO}_{2}(\rho=-0.60, p<0.001$, Fig S3). Archaeal richness was

244 positively correlated to distance below water-table $(\rho=0.83, p<0.001$, Fig S3). The

245 number of singletons observed in each site directly correlated with richness and

246 varied between sites $\left(r^{2}\right.$ adj $=0.97, p<0.001$, Fig S4, Equations S1 d-g).

\section{$247<$ Fig 3, $80 \mathrm{~mm}$ wide>}

\section{Site assembly dynamics}

249 Links have been drawn between a community's diversity, functional and phylogenetic

250 redundancy (robustness), and the community's ability to maintain function during Wiley-Blackwell and Society for Applied Microbiology 
bioRxiv preprint doi: https://doi.org/10.1101/143578; this version posted May 29, 2017. The copyright holder for this preprint (which was not

certified by peer review) is the author/funder, who has granted bioRxiv a license to display the preprint in perpetuity. It is made available unage $\mathbf{1 0}$ of $\mathbf{4 3}$ aCC-BY-NC-ND 4.0 International license.

251 change (resistance), and to recover original state if the disturbance is removed

252 (resilience) (Shade et al., 2012; Venail and Vives, 2013). While the degree to which

253 phylogenetic and/or functional diversity influence resistance is not fully elucidated,

254 recent studies support (Werner et al., 2011; Singh et al., 2014), these are important

255 properties to consider with climate change and permafrost thaw, two interacting

256 press disturbances at Stordalen (Shade et al., 2012; Hayes et al., 2014). A press

257 disturbance is a change in the environment that persists for a long period of time, in

258 comparison to a pulse disturbance which is a change that decreases suddenly after

259 a short period of time. Phylogenetic robustness can be measured by various

260 diversity relationships including phylogenetic distance between OTUs (PD); nearest

261 taxon index (NTI), which examines phylogenetic clustering of closely related

262 phylotypes; and mean relatedness index (NRI) which examines variance of

263 phylotype distance within an assemblage. Further, these indices can indicate the

264 relative degree to which stochastic or deterministic processes contribute to

265 community assembly (Wang et al., 2013). The Mire as a whole and each site

266 individually had positive correlation $\left(r^{2}\right.$ adj $=0.73$ to $\left.0.94, p<0.001\right)$ between overall

267 phylogenetic diversity (PD) and richness (Eqs S2a-d, Fig S5). Because PD and

268 richness were auto-correlated, subsequent analyses examined PD/OTU so as to

269 examine only the difference due to diversity and not an artefact of abundance

270 counts. Fen PD/OTU was significantly $(p<0.001)$ higher than both bog and palsa

271 assemblages (Fig 4). Measuring assemblage net relatedness (NRI, equivalent to -

272 sesMPD) by OTU phylogenetic distance from sample mean as generated by the null

273 model examines clustering over a whole tree. Greater emphasis is placed on

274 changes towards the tree root compared to other measures such as NTI, which

275 examines diversity at the tips of the phylogenetic tree. Negative values of NRI

276 indicate expansion of the tree via increased branching at higher-level tree nodes i.e.

277 even-dispersal, while positive values indicate filling in of internal phylogenetic tree

278 nodes i.e. clustering. Palsa assemblages had uniformly high NRI, $(0.1<\mathrm{NRI}<0.4$, Wiley-Blackwell and Society for Applied Microbiology 

aCC-BY-NC-ND 4.0 International license.

279 Fig 4) indicative of phylogenetic clustering. A deterministic factor associated with

280 clustering specific to the palsa (and surface bog) is dry-ombrotrophy which increases

281 habitat isolation in heterogeneous soil environments (Kraft et al., 2007; Jones et al.,

282 2009; Stegen et al., 2013; Quiroga et al., 2015). Fen assemblage NRls were

283 significantly lower than the other sites (KW, $\mathrm{p}<0.001$, Fig 4) and were neutral to

284 negative. Bog assemblage NRIs varied $(0<\mathrm{NRI}<0.4)$ from neutral in deeper

285 samples to higher than some Palsa in surface samples (Fig 4, Fig S5, Eq S4). The

286 lower NRI in the fen indicates assemblages have broader representation across the

287 bacterial and archaeal domains with less clustering than predicted by the null model

288 i.e. phylogenetic even dispersal. Even dispersal can indicate an assemblage less

289 affected by deterministic processes such as habitat filtering or isolation (Webb et al.,

290 2002; Horner-Devine and Bohannan, 2006), while being more affected by stochastic

291 processes such as dispersal and drift or controversially, by competition (Mayfield and

292 Levine, 2010). All assemblage NTI values were above zero, i.e. more clustered than

293 predicted with the null model, a result seen in early stage successional forests and

294 freshwater mesocosms, (Horner-Devine and Bohannan, 2006; Whitfeld et al., 2012).

295 The bog and fen had greater phylogenetic tip clustering than the palsa $(\mathrm{KW} p<0.05$,

296 Fig 4) and was, in the bog, related to depth (Eq S3). Greater tip-clustering as seen in

297 the bog and fen indicates greater genomic diversification within 'species'-

298 populations. This could be achieved through horizontal gene transfer (HGT) or

299 endogenous mutation enabling more closely related organisms to coexist (Goberna

300 et al., 2014), though there is not yet data to address effective population sizes, or the

301 relative frequencies of HGT and endogenous genome mutation in these habitats.

302 The ratio of NRI to NTI indicates the level (tree:tip) at which phylogenetic diversity is

303 affected by assembly processes. Fen assemblages had significantly greater

304 clustering at the whole tree level than tree tip when compared to the other sites

305 (NRI/NTI, Fig 4, p<0.01). Conversely, the palsa assemblages displayed greater

306 clustering towards the tree's tips. The bog NRI/NTI was in-between the palsa and the 
bioRxiv preprint doi: https://doi.org/10.1101/143578; this version posted May 29, 2017. The copyright holder for this preprint (which was not

certified by peer review) is the author/funder, who has granted bioRxiv a license to display the preprint in perpetuity. It is made available unage $\mathbf{1 2}$ of $\mathbf{4 3}$ aCC-BY-NC-ND 4.0 International license.

307 fen. This shift in where the assemblage diversity lies supports clustering through

308 local species divergence being a property of the ombrotrophic mire sites while even-

309 dispersal is more prevalent in the minerotrophic fen. The clustering shift from tip to

310 whole tree diversity is also seen at a smaller scale within the bog site (Fig S5, Eq S5)

311 where surface samples have higher tip clustering and deeper samples have more

312 evenly distributed diversity. That the mid depth bog samples were taken at the

313 waterline supports that a main factor regulating this shift is inundation by water.

314 Phylogenetic diversity of Mire assemblages as measured through PD, NRI, and NTI

315 showed the bog grouping alternately with the palsa or the fen supporting that the bog

316 may be an intermediate site undergoing transition from a palsa-like assemblage to

317 fen-like assemblage due to a shift from ombrotrophy to minerotrophy. These four

318 phylogenetic distance analyses support that each site has a unique overall

319 phylogenetic diversity profile, thus giving support to there being differences in

320 assembly and evolution of the microbial community across sites and therefore thaw

321 stages (Stegen et al., 2012).

322 Examining correlations between environmental parameters and phylogenetic

323 diversity can potentially inform on the relative contribution, directly or indirectly, of

324 environmental to assembly processes. Phylogenetic clustering related to

325 environmental filtering is predicted to be evident in environments with poor nutrient

326 availability or parameters considered to increase selection such as high acidity.

327 Phylogenetic evenness, conversely, is expected to be evident in environments with

328 high resource availability where competition becomes more dominant in assembly

329 processes. Increasing soil $\mathrm{pH}$, ratio of methanogens to methylotrophs, $\mathrm{CH}_{4}$ flux, and

330 distance below watertable were significantly correlated to increasing PD/OTU and

331 decreasing NRI and NRI/NTI ( $\rho \geq \pm 0.60, p<0.001$, Table S2, Fig S6) i.e. associated

332 with phylogenetic even dispersal. Greater depletion of ${ }^{13} \mathrm{C}_{\mathrm{CH} 4}$, higher porewater

$333 \mathrm{DOC}$, and higher porewater $\mathrm{C}: \mathrm{N}$ ratios were correlated to decreasing PD/OTU and

334 increasing NRI, and NRI/NTI i.e. phylogenetic clustering $(\rho \geq \pm 0.60, p<0.001$, Table Wiley-Blackwell and Society for Applied Microbiology 
335 S2). Only bog and fen porewater DOC and $\mathrm{C}: \mathrm{N}$ were analysed as there was

336 insufficient moisture in the palsa samples. Conditions associated with environmental

337 filtering (acidity) and isolation (ombrotrophy) may here be linked to phylogenetic

338 clustering (Kraft et al., 2007). Stochastic mechanisms specific to the fen include

339 inflow of runoff from the raised palsa and bog, minerotrophy, and local water mixing

340 which reduces isolation (Putkinen et al., 2012). Conditions associated with

341 phylogenetic even-dispersal may therefore be linked to warming potential (increased

$342 \mathrm{CH}_{4}$ flux) and increases in acetotrophic methanogens (less depletion of ${ }^{13} \mathrm{C}$ in $\mathrm{CH}_{4}$

343 emissions) in methanogenic soils. Clustering is an emerging characteristic of soil

344 communities (Lozupone and Knight, 2007; Auguet et al., 2010) that is currently

345 connected to habitat filtering (Kraft et al., 2007; Shade and Handelsman, 2012)

346 though some recent evidence also supports a role for biotic filtering (Goberna et al.,

347 2014). The correlations between higher phylogenetic diversity, including even-

348 dispersal, and $\mathrm{CH}_{4}$ flux corroborate findings from reactors and environmental

349 systems (Werner et al., 2011; Yavitt et al., 2011) that the structure of microbial

350 communities may be significant to global $\mathrm{CH}_{4}$ budgets.

$351<$ Fig 4, $80 \mathrm{~mm}$ wide>

352 Network topology and community interactions

353 Microbial networks can be described mathematically by topological indices. Common

354 indices include degree, modularity, betweenness, and closeness. Degree describes

355 the level of connectedness between phylotypes by counting the number of

356 phylotypes that co-occur. Modularity identifies if sub-networks of co-occurrence exist

357 within a larger community network and is thought to be an indicator of resilience.

358 Betweenness Centrality provides information on how critical a phylotype is to the

359 connectedness of a network. Closeness Centrality describes how closely a phylotype

360 is connected to all others in the same module. Redundancy (e.g similar metabolic

361 strategies) is also a useful descriptor of co-existing organisms. Degree, closeness

362 and redundancy in microbial networks provide information on the community's Wiley-Blackwell and Society for Applied Microbiology 
bioRxiv preprint doi: https://doi.org/10.1101/143578; this version posted May 29, 2017. The copyright holder for this preprint (which was not

certified by peer review) is the author/funder, who has granted bioRxiv a license to display the preprint in perpetuity. It is made available uRage 14 of $\mathbf{4 3}$ aCC-BY-NC-ND 4.0 International license.

363 robustness and, potentially, ability to resist change. OTU Table $B_{2000}$ had 9700

364 unique phylotypes, 93\% sparsity, average inverse Simpsons $\left(\mathrm{n}_{\text {eff }}\right)$ of 122 per sample

365 which was too sparse to obtain meaningful network information from. Restricting the

366 dataset to OTUs that were present in at least 15 samples (one third of total) left 257

367 unique OTUs, a table with $49 \%$ sparsity, and an average $n_{\text {eff }}$ of 26 , statistics that

368 provide assurance that network interactions could be correctly identified while

369 minimising type I errors (Friedman and Alm, 2012; Berry and Widder, 2014; Weiss et

370 al., 2016). Retaining only OTU pairs that were significantly correlated in at least two

371 of the network analyses from MENA, fastLSA, CoNet (Pearsons, Spearman, Bray,

$372 \mathrm{KBL}$ ), and SparCC reduced the dataset to 123 OTUs with 265 significant pairwíse

373 correlations (Table S3). The network had low degree (average 4.3 per node), a

374 maximum path of 14 , and low checkerboard $(\mathrm{C}$-score $=0.387)$. The $\mathrm{C}$-score was

375 compared to the null model and found to be different (null model C-score $=0.338$ )

376 with a $97.5 \% \mathrm{Cl}$ and $p<0.001$ supporting non-random OTU co-occurrence patterns

377 and the presence of a microbial network. However the work by Berry and Widder

378 (2014) examining the effect of filtering on sensitivity indicates that type II errors may

379 be as high as 0.5 based on $16-20 \%$ of the network potentially being habitat

380 specialists (Table S4). Analysis and visualisation of this network (Fig 5) revealed a

381 community consisting of 8 modules.

382 The detection of phylotypes in different environments, and their network topological

383 description, enables exploration of community metabolic roles of microbial lineages

384 (Foster et al., 2008). Highly connected phylotypes sometimes called hubs or

385 keystones (high degree, high closeness, low betweenness) are predicted to perform

386 key metabolic steps within microbial communities. In the identified network at

387 Stordalen only hubs with high degree, high closeness but with high betweenness

388 were identified (Fig 5, Table S3 \& S4). Due to their high betweenness and close

389 phylogenetic relatedness to adjacent OTUs these hubs exhibit qualities associated

390 with redundancy or 'niche overlap' and therefore may have little effect if removed i.e.

Wiley-Blackwell and Society for Applied Microbiology 
391 they are unlikely keystone species. Keystone species, while sometimes described

392 statistically as hubs (Faust and Raes, 2012; Berry and Widder, 2014), are

393 ecologically those that would cause (disproportionate) disruption to a network if lost.

394 In the larger modules of the network, there were a few phylotypes (putative

395 keystones marked on Fig 5, Table S3, S4) that if removed would fragment the 396 network and/or were the only phylotypes identified as associated with a critical 397 metabolic process. The loss of any of the identified keystone phylotypes from any of 398 the three sites, past or future, could affect significant changes in $\mathrm{C}, \mathrm{N}, \mathrm{S}$, or Fe 399 cycles at Stordalen. Identification of keystone species is problematic if there is a high 400 degree of type II errors or, as is expected with environmental phylogenetic-amplicon 401 surveys, there is limited information available on their phenotypes. Statistically, the 402 predicted keystones in this network cover the full range of betweenness and 403 closeness scores but none had high degree, supporting that high degree is a poor 404 predictor of 'keystoneness' in soil microbial communities.

405 Module 'A' consisted of 25 phylotypes (19 Acidobacteria, 4 Actinobacteria, 2 406 Euryarchaeota) that were dominant in the bog (Fig 5, Table S4). Two of the 407 Acidobacteriaceae (subgroup I Acidobacteria) phylotypes were identified as hubs.

408 The potential keystones (based on topology) were another Acidobacteraceae and 409 the less abundant of the two Ca. Methanoflorens (RCII) phylotypes. Ca. 410 Methanoflorens is a hydrogeno/formatotrophic methanogen of the Methanocellales 411 order that prefer low $\mathrm{H}^{2}$ concentration, and are oxygen and acid tolerant (Sakai et al., 412 2010; Lü and Lu, 2012; Mondav et al., 2014; Lyu and Lu, 2015). One of the three 413 Acidobacteria identified at genus level was a phylotype of Ca. Solibacter. Solibacter 414 are capable of degrading complex-C molecules such as cellulose, hemicellulose, 415 pectin, chitin, and starch (Ward et al., 2009; Pankratov et al., 2012), a useful 416 phenotype in the sphagnum-peat of the bog. Another was an Acidobacterium that 417 may be able to reduce ferric iron (Coupland and Johnson, 2008). The last of the 418 genus level identified was an Acidcapsa which likely preferentially utilise bi-products Wiley-Blackwell and Society for Applied Microbiology 
bioRxiv preprint doi: https://doi.org/10.1101/143578; this version posted May 29, 2017. The copyright holder for this preprint (which was not

certified by peer review) is the author/funder, who has granted bioRxiv a license to display the preprint in perpetuity. It is made available uRage $\mathbf{1 6}$ of $\mathbf{4 3}$ aCC-BY-NC-ND 4.0 International license.

419 of sphagnum degradation such as xylose or cellobiose, but if necessary could

420 directly degrade starch and pectin (Kulichevskaya et al., 2012; Matsuo et al., 2016).

421 The four Acidimicrobiales identified might contribute to Fe-cycling and likely capable

422 of degrading complex polymers (Kämpfer, 2010; Stackebrandt, 2014). The remainder

423 of module A (unknown Acidobacteraceae) are likely chemoheterotrophs that either

424 degrade sphagnum derived polymers or their hydrolysed bi-products (Campbell,

425 2014). Eighty percent of module A phylotypes had significant positive correlations ( $\rho$

$426 \geq \pm 0.60, p_{a d}<0.001$, Table S5) with porewater N, DOC concentration.

427 Module $\mathrm{B}^{\text {total }}$ was the most phylogenetically and phenotypically mixed module, it was

428 further divided into two sub-modules: B and B'. Thirty-four of module B phylotypes

429 were only detected in the fen, eight in both bog and fen samples, and three in both

430 fen and palsa samples. Module B hubs included both of the Bacteroidetes

431 phylotypes, a Woesearchaeota (DHVEG-6) and a Methanosaeta, and a

432 Methanoregula and a Bathyarchaeota (Msc. Crenarcheaota Grp) (Fig 5, Table S4).

433 The Bacteroidetes phylotypes are likely anaerobic, organotrophs with a preference

434 for sugar molecules (Krieg et al., 2010). Methanosaeta are obligate acetotrophic

435 methanogens and their higher substrate (acetate) affinity may be one mechanism

436 enabling them to compete in the fen (Westermann et al., 1989; Ferry, 2010; Liu et al.,

437 2010) as would the higher $\mathrm{pH}$ and reduction in inhibitory phenolics compared to

438 conditions in the bog. A Methanoregula phylotype was also identified as a hub, the

439 only potentially hydrogenotrophic (\&/or formatotrophic) methanogen in module B. Its

440 requirement for and greater tolerance of acetate, might assist Methanosaeta by

441 using up some of the available acetate (Smith and Ingram-Smith, 2007; Bräuer et al.,

442 2011; Oren, 2014b). No phenotypic data is yet available for Woesearchaeota. and

443 the Bathyarchaeota so far described were either methanogenic, methanotrophic, or

444 organoheterotrophic (Butterfield et al., 2016; Lazar et al., 2016). So while no

445 predictions can be made as to whether these phylotypes are e.g. methanogens, it is

446 evident that they are important methanogenic-community members. One of the Wiley-Blackwell and Society for Applied Microbiology 
447 methanogenic phylotypes connected to the Woesearchaeota and Bathyarchaeota

448 was a methylotrophic-methanogen of the Methanomassiliicoccus genus (Borrel et

449 al., 2013). Module B and B' were connected by the co-occurrence of one of these

450 Bathyarchaeota and a Methanobacterium respectively, both possible keystones. The

451 other putative keystones were an actinobacterial phylotype of the Gaiellales order of

452 unknown but likely heterotrophic metabolism, and the chemolithoautotrophic

453 Nitrospiraceae (Daims, 2014). It is probable that the Nitrospiraceae phylotype, which

454 was not detected in the bog, contributes to the module by C-fixation (Daims, 2014).

455 Two other module B phylotypes not in the bog were a chemoorganotrophic

456 (putative complex-C degrader) Myxococcales genus Haliangium (Kim and

457 Liesack, 2015), and an uncultured Chloroflexi KD4-96. The thirteen OTUs of 458 module B' were either not detected or detected at very low abundance in the palsa 459 (Fig 5, Table S4). All B' phylotypes were methanogens from either the 460 hydrogeno/formatotrophic Methanobacterium genus or the metabolically flexible 461 Methanosarcina genus (Oren, 2014a, 2014c). Module B', and to a lesser extent B, 462 displays the functional redundancy and phylogenetic clustering characteristic of soil 463 communities and in particular methanogenic soils (Embree et al., 2014). Module B 464 phylotypes $(87 \%)$ were strongly correlated $\left(\rho \geq \pm 0.60, p_{a d j}<0.001\right.$, Table S5) to 465 phylogenetic even dispersal (NRI), pH, CH4 flux, and decreasing porewater $\mathrm{N}$.

466 Module C consisted mainly of Xanthomonadales an order of obligate aerobic 467 Gammaproteobacteria capable of degrading complex organic molecules and 468 participating in methyl / $\mathrm{H}$ syntrophic partnerships with methylotrophs (Kim and 469 Liesack, 2015). The co-presence of the keystone methylotrophic proteobacterial 470 Methylotenera (Doronina et al., 2014) phylotype supports the possibility that such 471 partnerships occur at Stordalen and are common in the aerobic partition of 472 methanogenic soils. A second keystone phylotype was the C-fixing verrucomicrobial 473 methanotroph Methylacidiphilum (Hedlund, 2010; Sharp et al., 2013). The final 
bioRxiv preprint doi: https://doi.org/10.1101/143578; this version posted May 29, 2017. The copyright holder for this preprint (which was not

certified by peer review) is the author/funder, who has granted bioRxiv a license to display the preprint in perpetuity. It is made available uRage $\mathbf{1 8}$ of $\mathbf{4 3}$ aCC-BY-NC-ND 4.0 International license.

475 may also have a syntrophic partner within module C (Coupland and Johnson, 2008;

476 Johnson and Hallberg, 2008). Most phylotypes (12 of 16) were correlated to

477 increased clustering (NRI) and acidity (Table S5).

478 Module D consisted of 14 OTUs, nine Acidobacteria, four Gammaproteobacteria

479 (Xanthomonadales), and one Verrucomicrobia all of whom were dominant in the

480 palsa. Three keystones were identified, a subdivision 2 Acidobacteria, a Bryobacter

481 (subdivision 3 Acidobacteria), and a putatively ferric iron reducing Acidobacterium

482 (subdivision 1 Acidobacteria) phylotype. Bryobacter are chemoheterotrophs with a

483 preference for sugars (Dedysh et al., 2016). This module appears to have members

484 that together degrade complex-C molecules, polysaccharides and simple sugars

485 (Hedlund, 2010; Dedysh et al., 2016; Yang et al., 2016). Twelve of the phylotypes

486 had significant correlation ( $\rho \geq \pm 0.60, p_{\text {adj }}<0.001$, Table S5) with distance above

487 frozen ground/watertable. Module E had five Syntrophobacterales phylotypes,

488 putative producers of substrates for methanogenesis (acetate, $\mathrm{H}$, and formate) and

489 capable of $\mathrm{N}$ fixation (Embree et al., 2014; Lin et al., 2014), with four from the

490 Smithella genus and one from Syntrophus. None of these five were detected in palsa

491 samples. The final OTU of the module was detected across the mire and identified

492 as belonging to the Verrucomicrobia OPB35 soil group which is thought to degrade

493 polysaccharides (Hedlund, 2010; Yang et al., 2016). All of module E phylotypes were

494 significantly correlated with increasing $\mathrm{CH}_{4}$ flux and decreasing $\mathrm{NRI}(\rho \geq \pm 0.60$,

$495 \mathrm{p}_{\mathrm{adj}}<0.001$, Table S5).

496 Overall, the clustering of closely related phylotypes in modules is consistent with the

497 phylogenetic diversity results. The network associations of methanogen phylotypes

498 were complex and modular, with most falling into sub-network B' (present in bog and

499 fen and low abundance in palsa), followed by B (fen only, except for the more

500 cosmopolitan Methanomasilliicoccus phylotype). The two outlying Ca.

501 Methanoflorens methanogens in module A (fen and bog) were associated with

502 Acidobacteria and Actinobacteria which are typical of peat environments and The Wiley-Blackwell and Society for Applied Microbiology 
503 presence of permafrost fits the known distribution of this genus (Mondav et al., 2014)

504 and its predicted phenotype. The putative C-fixing autotrophs were scattered through

505 the network and only moderately connected, supporting their phylogenetically-based

506 assignments to a primary trophic role.

$507<$ Fig 5, $169 \mathrm{~mm}$ wide>

508 Known C-cycling phylotypes

509 Distinct shifts in relative abundances of putative methanogens, and methylotrophs

510 were evident across the Mire. Relative abundance of methanogens increased across

511 the thaw gradient (palsa<bog<fen, Table S6) $(\mathrm{K}-\mathrm{Wmc}, \mathrm{p}<0.001)$. Methanogens were

512 strongly associated with the deepest bog and fen samples (Table S6, Fig S7). All but

513 one of the obligate acetotrophic methanogens (Methanosaeta) were detected

514 exclusively in the fen (Fig S7), the other one was found in a single palsa sample.

515 Apart from the anomalous Methanosaeta detected in the palsa, this is consistent with

516 reported acetotrophic sensitivity to low $\mathrm{pH}$ due to reduction of the $\Delta \mathrm{G}$ (Gibbs free

517 energy) of the acetotrophic methanogenesis pathway (Kotsyurbenko et al., 2007).

518 The possibility of a divergent metabolism may explain the presence of the

519 Methanosaeta in the palsa. Other methanogenic phylotypes detected in apparently

520 aerobic samples (above the water line) may have been enabled by micro-anaerobic-

521 habitats, oxidative resistance as seen in some Methanocellales (Angel et al., 2011),

522 or association with an anaerobic host gut (Paul et al., 2012). Putative

523 methano/methylotrophic phylotypes were distributed across all samples (Fig S7) and

524 were highest in the bog samples (K-Wmc, $p<0.01$, Table S6) likely accounting for the

525 lower $\mathrm{CH}_{4}$ flux despite the abundance of methanogens. Some methylotrophs were

526 detected below the waterline in bog and fen samples (Fig S7) and likely exist in

527 micro-aerobic spaces enabled by plant root gas transport (Colmer, 2003). The

528 relative ratio of methanogen to methanotroph phylotypes differed significantly

529 between sites (K-Wmc, $\mathrm{p}<0.01)$, increasing across the thaw gradient

530 (palsa<bog<fen, Table S6). Due to the polyphyletic distribution of autotrophic and Wiley-Blackwell and Society for Applied Microbiology 
bioRxiv preprint doi: https://doi.org/10.1101/143578; this version posted May 29, 2017. The copyright holder for this preprint (which was not

certified by peer review) is the author/funder, who has granted bioRxiv a license to display the preprint in perpetuity. It is made available unage $\mathbf{2 0}$ of $\mathbf{4 3}$ aCC-BY-NC-ND 4.0 International license.

531 methanotrophic metabolisms the assignment of function requires identification to

532 family or genera level, while most methanogens can be identified at class or order

533 level. It is therefore likely that abundances and richness of autotrophic and

534 methanotrophic microbes described here are underestimated more than

535 methanogens. The shifting C-cycling phylotype patterns described here, especially

536 the methanogen to methanotroph ratio provide detail of biogenic methane production

537 and consumption that support reported site C-budgets (Bäckstrand et al., 2010), $\mathrm{CH}_{4}$

538 emissions and $\mathrm{CH}_{4}$ isotope ratios (McCalley et al., 2014) from Stordalen.

539 The presence of permafrost maintains the ombrotrophic, acidic environment (Natali

540 et al., 2011; Tveit et al., 2013) which correlated with a diverse, rich, phylogenetically-

541 clustered, and autotroph-abundant palsa community. The bog sites (thawing

542 permafrost) had significantly lower richness, diversity, evenness and estimated

543 population size than the palsa, the fen, and also other peat bog sites (Lin et al.,

544 2012; Serkebaeva et al., 2013; Tveit et al., 2013). Collectively, this suggests a

545 structural response to ecosystem disturbance (Degens et al., 2001) caused by site

546 inundation as a consequence of subsidence caused by permafrost thaw (Rydén et

547 al., 1980; Johansson and Åkerman, 2008). Correlations between diversity estimates

548 (alpha, beta, and phylogenetic) and distance of sample above or below the water

549 table support that site inundation (and therefore thaw) is a mechanistic driver of

550 community structure and function and that deterministic processes were the main

551 drivers of community composition and assembly in this and other bogs (Quiroga et

552 al., 2015). Complete loss of permafrost in the fen was correlated to assemblages

553 with highest richness, alpha diversity, beta diversity, and phylogenetic even-

554 dispersion.

555 As the permafrost thaws, causing subsidence, Palsas and transitory bogs at

556 Stordalen mire are expected to give way to fens. At Stordalen the transition from bog

557 to fen is accompanied by community diversification and proliferation of methanogens

558 and a decrease in the relative ratio of methanotrophs. It appears at Stordalen, as Wiley-Blackwell and Society for Applied Microbiology 

aCC-BY-NC-ND 4.0 International license.

559 found elsewhere under similar conditions (Liebner et al., 2015), that at the point of

560 inundation a regime shift is initiated and that beyond this point, the community does

561 not recover but instead shifts towards a new stable state as found in the fen. The fen

562 assemblage has qualities indicative of greater stability (high redundancy, evenness,

563 richness, and diversity) coincident with an altered C-budget of dramatically higher

564 warming potential. The combination of changes predicted by climate models, the

565 trajectory suggested in biogeochemical and vegetation surveys of the Mire, and the

566 details of the microbial community C-cycling shifts detailed here suggest that the

567 mires along the Torneträsk valley will increasingly add to radiative climate forcing via

568 increased $\mathrm{CH}_{4}$ flux over the coming decades as more land is converted to fen.

569 Longer-term outcomes of climate change in this region are projected to eventually

570 include some drying (e.g. terrestrialisation, the conversion of wetlands to drier areas

571 (Payette et al., 2004)) and expansion of the dwarf forests (Rundqvist et al., 2011). If

572 these fundamental habitat shifts occur, they are extremely likely to drive further

573 changes in the microbial communities and $\mathrm{C}$ budgets of the region.

575 Experimental Procedures

576 Field site and sampling

577 Samples were taken from the active layer of an individual palsa thaw sequence in

578 Stordalen Mire, subarctic Sweden (68.35N, 19.04E), with three stages of permafrost

579 degradation evidenced by topographical and vegetative characteristics (intact,

580 thawing, and thawed; Fig S1). The intact permafrost was represented by a raised

581 section of the palsa (palsa site, Fig S2); the thawing transition site was an

582 elevationally depressed region within the palsa (bog site); and the thawed permafrost

583 was a thermokarst feature with no detectable permafrost and thus no apparent

584 seasonal active layer (fen site) (Rydén et al., 1980; Malmer et al., 2005). The palsa

585 site was an ombrotrophic, drained, raised peat (altitude 351 m.a.s.I (Jackowicz-

586 Korczyński et al., 2010)) with tundra vegetation including Betula nana and Empetrum Wiley-Blackwell and Society for Applied Microbiology 
bioRxiv preprint doi: https://doi.org/10.1101/143578; this version posted May 29, 2017. The copyright holder for this preprint (which was not

certified by peer review) is the author/funder, who has granted bioRxiv a license to display the preprint in perpetuity. It is made available unage $\mathbf{2 2}$ of $\mathbf{4 3}$ aCC-BY-NC-ND 4.0 International license.

587 hermaphroditum, interspersed with Eriophorum vaginatum, Rubus chamaemorus,

588 lichens, and mosses. The bog site was a wet ombrotrophic depression sunken $\sim 1 \mathrm{~m}$

589 below the palsa. Vegetation was predominately Sphagnum spp. with E. vaginatum.

590 Water table varied seasonally from $5 \mathrm{~cm}$ above to $30 \mathrm{~cm}$ below the vegetation

591 surface and was perched above the local groundwater. The average $\mathrm{pH}$ of the

592 ombrotrophic sites was $4.2+/-0.3 \mathrm{sd}$. The fen site was a minerotrophic, waterlogged

593 fen $\sim 2$ m below the palsa, vegetation was dominated by Eriophorum angustifolium

594 with some Sphagnum spp. and Equisetum spp., and open water was present. The

595 water table was always within $5 \mathrm{~cm}$ of the peat surface, sometimes being above it,

596 and average $\mathrm{pH}$ of $5.7+/-0.1 \mathrm{sd}$.

597 Soil cores were taken in August/September 2010 and June, July, August, and

598 October 2011 (Table S1, Table S7). On each of the five sampling dates, between two 599 and four cores were taken from each of the three sites (Fig S1). In 2010 four cores

600 were taken from palsa and bog sites, in October 2011 two cores were taken from the

601 fen site, and all remaining sampling dates and locations had three cores sampled.

602 Samples cut from cores taken from the same site, at either the same depth in $\mathrm{cm}$ or

603 the same ecologically significant depth (e.g. depth relative to water table) were

604 designated technical replicates. Samples taken at different depths were analysed as

605 treatments (Samples taken at different depths were selected based on ecologically

606 pre-determined indicators such as at the water table for the bog, Fig S2). Porewater,

607 peat, flux and isotope measurements taken simultaneously to the microbial samples

608 were described in Mondav et al. (2014), Hodgkins et al. (2014) and McCalley et al

609 (2014) but are detailed again in the Supplementary Methods.

610 SSU rRNA gene amplicon sequencing and analysis

611 Microbial community was surveyed by small subunit (SSU) rRNA gene amplicon

612 sequencing (Mondav et al., 2014). Briefly, DNA was amplified with tagged primers for

613 V6-V8 region of the SSU rRNA gene with the 926F (AAACTYAAAKGAATTGRCGG)

614 and 1392wR (ACGGGCGGTGWGTRC) primers, in duplicate reactions, pooled, and Wiley-Blackwell and Society for Applied Microbiology 

aCC-BY-NC-ND 4.0 International license.

615 sequenced with the 454 Ti GS (LifeSciences, Carlsbad). Sequences are available

616 from SRA under accession SRA096214 (McCalley et al., 2014; Mondav et al., 2014),

617 SRR numbers and primer details are listed in detail in Table S1. Sequences were

618 cleaned (pre-processed) with MacQIIME v1.9.1 then analysed at an operational

619 taxonomic unit (OTU) of $97 \%$ identity. A detailed description of pre-processing

620 methods can be found in the Supplementary Methods. Cleaned sequences were

621 assigned taxonomy using the open picking method and the SILVA database and a

622 phylogenetic tree made with Fasttree2 and manually rooted between the archaeal

623 and bacterial domains (Caporaso, Bittinger, et al., 2010; Caporaso, Kuczynski, et al.,

624 2010; Edgar, 2010; Price et al., 2010; Huson and Scornavacca, 2012; McDonald et

625 al., 2012; Quast et al., 2013). Phylotype lineage obtained by assignment of reads to

626 taxon identity was utilised to assign putative C-metabolism. Phylotypes that were

627 assigned to lineages with known methanogen, methanotroph/methylotroph, and C-

628 fixing members were manually checked before C-metabolism was assigned.

629 Microbial assemblages

630 Phylum level analysis was obtained by collapsing the normalised OTU table in

631 Qiime, and phyla detected in more than one sample and also present at over $1 \%$ in

632 at least one sample were graphed in MS Excel. To investigate dissimilarity of sample

633 and site assemblages a non-parametric ordination (NMDS) was done in R v3.3.1 (R-

634 Core-team, 2011) using the RStudio v0.99.903 (RStudio, 2012) IDE with the vegan

635 package v2.4-1 (Oksanen et al., 2013) and plotted using gplots v3.0.1 and with

636 scales v0.2.3 (Warnes et al., 2011). Environmental variables and parameters were

637 fitted to the NMDS and factors with significant $(p<0.05)$ correlation plotted. Alpha

638 diversity metrics were generated in Qiime (richness, singletons, Shannon diversity,

639 Fisher alpha, Heip's evenness, Simpson's dominance and Chao1 estimates) and

640 analysed in $\mathrm{R}$ using the non-parametric Kruskal-Wallis (K-W) followed by post-hoc

641 testing with Kruskal-Wallis multiple comparison ( $\mathrm{K}-\mathrm{Wmc}$ ) testing using $\mathrm{R}$ package

642 pgirmess v1.6.4 (Giraudoux, 2012). Correlation analyses were done using nonWiley-Blackwell and Society for Applied Microbiology 
643 parametric Spearman and linear regression and differences between sites were

644 checked for significance with the largest $p$ value obtained reported. Images were

645 processed for publication in Inkscape 0.91. Analysis of the phylogenetic diversity and

646 distance (PD, NRI, NTI) were calculated using the distance tree output from QIIME,

647 and correlation and equations calculated in R with picante v1.6-0 (Gotelli, 2000;

648 Faith, 2006; Kembel et al., 2010). OTUs present in less than 15 samples were

649 removed and the resultant OTU table analysed for pairwise interactions in MENA

650 (Deng et al., 2012), fastLSA (Durno et al., 2013), CoNet v1.1.1 (Faust et al., 2012)

651 and SparCC (Friedman and Alm, 2012). All networks were loaded into R and OTU

652 pairs that were identified as present in at least two of the four networks were retained

653 and the network analysed in CytoScape v3.4.0. See Supplementary Methods for

654 detailed description of all methods.

655

656 Supplementary Information is available as a separate download and includes

657 Supplementary Methods, Figs S1-S7, Equations S1-S5, and Tables S1-S7.

658

\section{Acknowledgements}

660 Many thanks to Andrew C Barnes, Brian Lanoil, and James Prosser for critical

661 comments on a previous version of the manuscript. Sincere thanks to the two

662 anonymous reviewers who helped me greatly improve this manuscript. RM was

663 supported by an Australian Postgraduate Award Scholarship and a Swedish

664 Vetenskapsrådet grant. JPC, PMC, SF, SH, CKM, SRS, and VIR were supported by

665 the US Department of Energy, Office of Biological and Environmental Research

666 under the Genomic Science program (Award DE-SC0004632).

667

\section{Author contributions}


669 JPC, PMC, SF, SRS, VIR designed the project. RM designed and performed all

670 bioinformatics analyses and visualizations. RM wrote the paper in consultation with

671 all authors.

672

\section{References}

674 Alewell, C., Giesler, R., Klaminder, J., Leifeld, J., and Rollog, M. (2011) Stable carbon 675 isotopes as indicators for environmental change in palsa peats. Biogeosciences 676 8: $1769-1778$.

677 Angel, R., Matthies, D., and Conrad, R. (2011) Activation of methanogenesis in arid 678 biological soil crusts despite the presence of oxygen. PLoS One 6: e20453.

679 Bäckstrand, K., Crill, P.M., Jackowicz-Korczyñski, M., Mastepanov, M., Christensen, 680 T.R., and Bastviken, D. (2010) Annual carbon gas budget for a subarctic 681 peatland, Northern Sweden. Biogeosciences 7: 95-108.

682 Bäckstrand, K., Crill, P.M., Mastepanov, M., Christensen, T.R., and Bastviken, D. 683 (2008) Total hydrocarbon flux dynamics at a subarctic mire in northern Sweden. J. Geophys. Res. 113: G03026.

Berry, D. and Widder, S. (2014) Deciphering microbial interactions and detecting keystone species with co-occurrence networks. Front. Microbiol. 5: 1-14.

687 Bhiry, N. and Robert, É.C. (2006) Reconstruction of changes in vegetation and 688 trophic conditions of a palsa in a permafrost peatland. Ecoscience 13: 56-65.

689 Borrel, G., O'Toole, P.W., Harris, H.M.B., Peyret, P., Brugère, J.-F., and Gribaldo, S. (2013) Phylogenomic data support a seventh order of Methylotrophic methanogens and provide insights into the evolution of Methanogenesis. Genome Biol. Evol. 5: 1769-80.

693 Bosiö, J., Johansson, M., Callaghan, T. V., Johansen, B., and Christensen, T.R. 694 (2012) Future vegetation changes in thawing subarctic mires and implications 695 for greenhouse gas exchange_-a regional assessment. Clim. Change 115: 379_ 696398. 
697 Bowers, R.M., McLetchie, S., Knight, R., and Fierer, N. (2011) Spatial variability in

698 airborne bacterial communities across land-use types and their relationship to

699 the bacterial communities of potential source environments. ISME J. 5: 601-

$700 \quad 612$.

701 Bräuer, S.L., Cadillo-Quiroz, H., Ward, R.J., Yavitt, J.B., and Zinder, S.H. (2011) 702 Methanoregula boonei gen. nov., sp. nov., an acidiphilic methanogen isolated 703 from an acidic peat bog. Int. J. Syst. Evol. Microbiol. 61: 45-52.

704 Brettar, I., Christen, R., and Höfle, M.G. (2011) Analysis of bacterial core 705 communities in the central Baltic by comparative RNA-DNA-based fingerprinting provides links to structure-function relationships. ISME J. 1-18.

707 Butterfield, C.N., Li, Z., Andeer, P.F., Spaulding, S., Thomas, B.C., Singh, A., et al. 708 (2016) Proteogenomic analyses indicate bacterial methylotrophy and archaeal heterotrophy are prevalent below the grass root zone. PeerJ 4: e2687. Heidelberg, pp. 405-415.

713 Caporaso, J.G., Bittinger, K., Bushman, F.D., Desantis, T.Z., Andersen, G.L., and 714 Knight, R. (2010) PyNAST: A flexible tool for aligning sequences to a template $715 \quad$ alignment. Bioinformatics 26: 266-267.

716 Caporaso, J.G., Kuczynski, J., Stombaugh, J., Bittinger, K., Bushman, F.D., Costello, 717 E.K., et al. (2010) QIIME allows analysis of high- throughput community sequencing data. Nat. Methods 7: 335-336.

719 Chanton, J.P., Whiting, G.J., Happell, J.D., and Gerard, G. (1993) Contrasting rates 720 and diurnal patterns of methane emission from emergent aquatic macrophytes. $721 \quad$ Aquat. Bot. 46: 111-128.

722 Christensen, T.R. (2004) Thawing sub-arctic permafrost: Effects on vegetation and 723 methane emissions. Geophys. Res. Lett. 31:.

724 Christensen, T.R., Jackowicz-Korczyński, M., Aurela, M., Crill, P.M., Heliasz, M., Wiley-Blackwell and Society for Applied Microbiology 
725 Mastepanov, M., and Friborg, T. (2012) Monitoring the Multi-Year Carbon

$726 \quad$ Balance of a Subarctic Palsa Mire with Micrometeorological Techniques. Ambio

$727 \quad 41: 207-217$.

728 Christensen, T.R., Johansson, T., Åkerman, J.H., Mastepanov, M., Malmer, N., 729 Friborg, T., et al. (2004) Thawing sub-arctic permafrost: Effects on vegetation $730 \quad$ and methane emissions. Geophys. Res. Lett. 31: 1-4.

731 Christner, B.C., Morris, C.E., Foreman, C.M., Cai, R., and Sands, D.C. (2008) $732 \quad$ Ubiquity of biological ice nucleators in snowfall. Science 319: 1214.

733 Colmer, T.D. (2003) Long-distance transport of gases in plants: a perspective on 734 internal aeration and radial oxygen loss from roots. Plant, Cell Environ. 26: 1773536.

736 Coupland, K. and Johnson, D.B. (2008) Evidence that the potential for dissimilatory 737 ferric iron reduction is widespread among acidophilic heterotrophic bacteria. $738 \quad$ FEMS Microbiol. Lett. 279: 30-35.

739 Daims, H. (2014) The family nitrospiraceae. In, The Prokaryotes: Other Major 740 Lineages of Bacteria and The Archaea. Springer Berlin Heidelberg, Berlin, $741 \quad$ Heidelberg, pp. 733-749.

742 Dedysh, S.N., Kulichevskaya, I.S., Huber, K.J., and Overmann, J. (2016) Defining 743 the taxonomic status of described subdivision 3 Acidobacteria: the proposal of

745 Degens, B.P., Schipper, L.A., Sparling, G.P., and Duncan, L.C. (2001) Is the microbial 746 community in a soil with reduced catabolic diversity less resistant to stress or 747 disturbance? Soil Biol. Biochem. 33: 1143-1153.

748 Deng, Y., Jiang, Y.H., Yang, Y., He, Z., Luo, F., and Zhou, J. (2012) Molecular 749 ecological network analyses. BMC Bioinformatics 13: 113.

750 Doronina, N., Kaparullina, E., and Trotsenko, Y. (2014) The Family Methylophilaceae. 751 In, The Prokaryotes. Springer Berlin Heidelberg, Berlin, Heidelberg, pp. 869$752 \quad 880$. 

aCC-BY-NC-ND 4.0 International license.

753 Dorrepaal, E., Toet, S., van Logtestijn, R.S.P., Swart, E., van de Weg, M.J.,

754 Callaghan, T. V., and Aerts, R. (2009) Carbon respiration from subsurface peat

$755 \quad$ accelerated by climate warming in the subarctic. Nature 460: 616-619.

756 Durno, W.E., Hanson, N.W., Konwar, K.M., and Hallam, S.J. (2013) Expanding the 757 boundaries of local similarity analysis. BMC Genomics 14 Suppl 1: S3.

758 Edgar, R.C. (2010) Search and clustering orders of magnitude faster than BLAST. 759 Bioinformatics 26: 2460-2461.

760 Embree, M., Nagarajan, H., Movahedi, N., Chitsaz, H., and Zengler, K. (2014) 761 Single-cell genome and metatranscriptome sequencing reveal metabolic interactions of an alkane-degrading methanogenic community. ISME J. 8: 757-

764 Faith, D.P. (2006) The role of the phylogenetic diversity measure, PD, in bio765 informatics: getting the definition right. Evol. Bioinform. Online 2: 277-83.

766 Faust, K. and Raes, J. (2012) Microbial interactions: from networks to models. Nat. Rev. Microbiol. 10: 538-50.

768 Faust, K., Sathirapongsasuti, J.F., Izard, J., Segata, N., Gevers, D., Raes, J., and Huttenhower, C. (2012) Microbial co-occurrence relationships in the human microbiome. PLoS Comput. Biol. 8: e1002606.

771 Fisher, R.A., Corbet, A.S., and Williams, C.B. (1943) The Relation Between the 772 Number of Species and the Number of Individuals in a Random Sample of an $773 \quad$ Animal Population. J. Anim. Ecol. 12: 42-58.

774 Foster, J. a, Krone, S.M., and Forney, L.J. (2008) Application of ecological network 775 theory to the human microbiome. Interdiscip. Perspect. Infect. Dis. 2008: $776 \quad 839501$.

777 Freeman, C., Ostle, N.J., Fenner, N., and Kang, H. (2004) A regulatory role for 778 phenol oxidase during decomposition in peatlands. Soil Biol. Biochem. 36: $779 \quad 1663-1667$.

780 Friedman, J. and Alm, E.J. (2012) Inferring correlation networks from genomic Wiley-Blackwell and Society for Applied Microbiology 
survey data. PLoS Comput. Biol. 8: e1002687.

782 Fronzek, S., Carter, T.R., Räisänen, J., Ruokolainen, L., and Luoto, M. (2010)

783 Applying probabilistic projections of climate change with impact models: a case

784 study for sub-arctic palsa mires in Fennoscandia. Clim. Change 99: 515-534.

785 Galand, P.E., Fritze, H., and Yrjala, K. (2003) Microsite-dependent changes in 786 methanogenic populations in a boreal oligotrophic fen. Environ. Microbiol. 5: $787 \quad 1133-1143$.

788 Giraudoux, P. (2012) pgirmess: Data analysis in ecology. R package version 1.5.6.

789 Goberna, M., García, C., and Verdú, M. (2014) A role for biotic filtering in driving 790 phylogenetic clustering in soil bacterial communities. Glob. Ecol. Biogeogr. 23: $791 \quad 1346-1355$.

792 Goberna, M. and Verdú, M. (2016) Predicting microbial traits with phylogenies. ISME 793 J. 10: 959-967.

794 Godin, A., McLaughlin, J.W., Webster, K.L., Packalen, M., and Basiliko, N. (2012) 795 Methane and methanogen community dynamics across a boreal peatland 796 nutrient gradient. Soil Biol. Biochem. 48: 96-105.

797 Gotelli, N.J. (2000) Null model analysis of species co-occurrence patterns. 81: 26067982621.

799 Gurney, S.D. (2001) Aspects of the genesis, geomorphology and terminology of 800 palsas: perennial cryogenic mounds. Prog. Phys. Geogr. 25: 249-260.

801 Hayes, D.J., Kicklighter, D.W., McGuire, A.D., Chen, M., Zhuang, Q., Yuan, F., et al. 802 (2014) The impacts of recent permafrost thaw on land-atmosphere greenhouse 803 gas exchange. Environ. Res. Lett. 9: 45005.

804 Hedlund, B.P. (2010) Phylum Verrucomicrobia phyl. n. In, Bergey's Manual® of 805 Systematic Bacteriology. Springer New York, New York, NY, pp. 795-841.

806 Heip, C., Hill, M.O., Pielou, E.C., and Sheldon, A.L. (1974) A New Index Measuring $807 \quad$ Evenness. J. Mar. Biol. Assoc. United Kingdom 54: 555.

808 Hicks Pries, C.E., Schuur, E.A.G., and Crummer, K.G. (2013) Thawing permafrost Wiley-Blackwell and Society for Applied Microbiology 
809 increases old soil and autotrophic respiration in tundra: partitioning ecosystem

$810 \quad$ respiration using $\delta(13) \mathrm{C}$ and $\Delta(14) \mathrm{C}$. Glob. Chang. Biol. 19: 649-61.

811 Hobbie, S.E., Schimel, J.P., Trumbore, S.E., and Randerson, J.R. (2000) Controls

812 over carbon storage and turnover in high-latitude soils. Glob. Chang. Biol. 6:

813 196-210.

814 Hodgkins, S.B., Tfaily, M.M., McCalley, C.K., Logan, T. a, Crill, P.M., Saleska, S.R., et 815 al. (2014) Changes in peat chemistry associated with permafrost thaw increase 816 greenhouse gas production. Proc. Natl. Acad. Sci. U. S. A. 111: 5819-5824.

817 Horner-Devine, M.C. and Bohannan, B.J.M. (2006) Phylogenetic clustering and 818 overdispersion in bacterial communities. Ecology 87: S100-S108.

819 Huson, D.H. and Scornavacca, C. (2012) Dendroscope 3: an interactive tool for 820 rooted phylogenetic trees and networks. Syst. Biol. 61: 1061-7.

821 Jackowicz-Korczyński, M., Christensen, T.R., Bäckstrand, K., Crill, P.M., Friborg, T., 822 Mastepanov, M., and Ström, L. (2010) Annual cycle of methane emission from a 823 subarctic peatland. J. Geophys. Res. 115: 1-10.

824 Johansson, M. and Åkerman, J.H. (2008) Thawing Permafrost and Thicker Active 825 Layers in Sub-arctic Sweden. Permafr. Periglac. Process. 19: 279-292.

826 Johansson, T., Malmer, N., Crill, P.M., Friborg, T., Åkerman, J.H., Mastepanov, M., et 827 al. (2006) Decadal vegetation changes in a northern peatland, greenhouse gas 828 fluxes and net radiative forcing. Glob. Chang. Biol. 12: 2352-2369.

829 Johnson, B.D. and Hallberg, K.B. (2008) Carbon, Iron and Sulfur Metabolism in 830 Acidophilic Micro-Organisms. Adv. Microb. Physiol. 54: 201-255.

831 Jones, M.C., Harden, J., O’Donnell, J., Manies, K., Jorgenson, T., Treat, C., and 832 Ewing, S. (2016) Rapid carbon loss and slow recovery following permafrost 833 thaw in boreal peatlands. Glob. Chang. Biol.

834 Jones, R.T., Robeson, M.S., Lauber, C.L., Hamady, M., Knight, R., and Fierer, N. 835 (2009) A comprehensive survey of soil acidobacterial diversity using 836 pyrosequencing and clone library analyses. ISME J. 3: 442-453. 

aCC-BY-NC-ND 4.0 International license.

837 Kämpfer, P. (2010) Actinobacteria. In, Handbook of Hydrocarbon and Lipid

838 Microbiology. Springer Berlin Heidelberg, Berlin, Heidelberg, pp. 1819-1838.

839 Kembel, S.W., Cowan, P.D., Helmus, M.R., Cornwell, W.K., Morlon, H., Ackerly, D.D.,

840 et al. (2010) Picante: $R$ tools for integrating phylogenies and ecology.

$841 \quad$ Bioinformatics 26: 1463-4.

842 Kim, Y. and Liesack, W. (2015) Differential assemblage of functional units in paddy 843 soil microbiomes. PLoS One 10:.

844 King, A.J., Farrer, E.C., Suding, K.N., and Schmidt, S.K. (2012) Co-occurrence 845 patterns of plants and soil bacteria in the high-alpine subnival zone track environmental harshness. Front. Microbiol. 3: 347.

847 Kokfelt, U., Reuss, N., Struyf, E., Sonesson, M., Rundgren, M., Skog, G., et al. (2010) Wetland development, permafrost history and nutrient cycling inferred from late Holocene peat and lake sediment records in subarctic Sweden. J.

851 Kotsyurbenko, O.R., Friedrich, M.W., Simankova, M. V, Nozhevnikova, a N., 852 Golyshin, P.N., Timmis, K.N., and Conrad, R. (2007) Shift from acetoclastic to $\mathrm{H}$ 2-dependent methanogenesis in a west Siberian peat bog at low $\mathrm{pH}$ values and isolation of an acidophilic Methanobacterium strain. Appl. Environ. Microbiol. 73: 2344-8.

859 Krieg, N.R., Staley, J.T., Brown, D.R., Hedlund, B.P., Paster, B.J., Ward, N.L., et al. (2010) Bergey's Volume 4 Bacteroidetes, Acidobacteria, Spirochaetes etc.

861 Kulichevskaya, I.S., Kostina, L.A., Valášková, V., Rijpstra, W.I.C., Sinninghe Damsté, 862 J.S., de Boer, W., and Dedysh, S.N. (2012) Acidicapsa borealis gen. nov., sp. 863 nov. and Acidicapsa ligni sp. nov., subdivision 1 Acidobacteria from Sphagnum 
865 Lazar, C.S., Baker, B.J., Seitz, K., Hyde, A.S., Dick, G.J., Hinrichs, K.U., and Teske,

866 A.P. (2016) Genomic evidence for distinct carbon substrate preferences and

867 ecological niches of Bathyarchaeota in estuarine sediments. Environ. Microbiol.

868 18: 1200-1211.

869 Liebner, S., Ganzert, L., Kiss, A., Yang, S., Wagner, D., and Svenning, M.M. (2015)

870 Shifts in methanogenic community composition and methane fluxes along the 871 degradation of discontinuous permafrost. Front. Microbiol. 6: 1-10.

872 Lin, X., Green, S., Tfaily, M.M., Prakash, O., Konstantinidis, K.T., Corbett, J.E., et al. 873 (2012) Microbial community structure and activity linked to contrasting biogeochemical gradients in bog and fen environments of the Glacial Lake Agassiz Peatland. Appl. Environ. Microbiol. 78: 7023-7031.

876 Lin, X., Tfaily, M.M., Green, S.J., Steinweg, J.M., Chanton, P., Imvittaya, A., et al.

877 (2014) Microbial metabolic potential for carbon degradation and nutrient 878 (nitrogen and phosphorus) acquisition in an ombrotrophic peatland. Appl. $879 \quad$ Environ. Microbiol. 80: 3531-40.

880 Lü, Z. and Lu, Y. (2012) Methanocella conradii sp. nov., a Thermophilic, Obligate 881 Hydrogenotrophic Methanogen, Isolated from Chinese Rice Field Soil. PLoS $882 \quad$ One 7: e35279.

883 Lyu, Z. and Lu, Y. (2015) Comparative genomics of three Methanocellales strains 884 reveal novel taxonomic and metabolic features. Environ. Microbiol. Rep. 7: 526$885 \quad 537$.

886 Mack, M.C., Bret-Harte, M.S., Hollingsworth, T.N., Jandt, R.R., Schuur, E.A.G., 887 Shaver, G.R., and Verbyla, D.L. (2011) Carbon loss from an unprecedented $888 \quad$ Arctic tundra wildfire. Nature 475: 489-92.

889 Malmer, N., Johansson, T., Olsrud, M., and Christensen, T.R. (2005) Vegetation, 890 climatic changes and net carbon sequestration in a North-Scandinavian 891 subarctic mire over 30 years. Glob. Chang. Biol. 11: 1895-1909.

892 Martiny, A.C., Treseder, K., and Pusch, G. (2013) Phylogenetic conservatism of Wiley-Blackwell and Society for Applied Microbiology 
893 functional traits in microorganisms. ISME J. 7: 830-8.

894 Masing, V., Botch, M., and Läänelaid, a. (2009) Mires of the former Soviet Union.

895 Wetl. Ecol. Manag. 18: 397-433.

896 Matsuo, H., Kudo, C., Li, J., and Tonouchi, A. (2016) Acidicapsa acidisoli sp. nov. 897 from the acidic soil of a deciduous forest. Int. J. Syst. Evol. Microbiol.

898 Mayfield, M.M. and Levine, J.M. (2010) Opposing effects of competitive exclusion on 899 the phylogenetic structure of communities. Ecol. Lett. 13: 1085-93.

900 McCalley, C.K., Woodcroft, B.J., Hodgkins, S.B., Wehr, R.A., Kim, E.-H., Mondav, R., 901 et al. (2014) Methane dynamics regulated by microbial community response to permafrost thaw. Nature 514: 478-481.

903 McDonald, D., Price, M.N., Goodrich, J., Nawrocki, E.P., DeSantis, T.Z., Probst, A., et 904 al. (2012) An improved Greengenes taxonomy with explicit ranks for ecological 905 and evolutionary analyses of bacteria and archaea. ISME J. 6: 610-8.

906 McGuire, A.D., Macdonald, R.W., Schuur, E.A.G., Harden, J.W., Kuhry, P., Hayes, 907 D.J., et al. (2010) The carbon budget of the northern cryosphere region. Curr. Opin. Environ. Sustain. 2: 231-236.

909 Mondav, R., Woodcroft, B.J., Kim, E.-H., McCalley, C.K., Hodgkins, S.B., Crill, P.M., 910 et al. (2014) Discovery of a novel methanogen prevalent in thawing permafrost. $911 \quad$ Nat. Commun. 5: 1-7.

912 Natali, S.M., Schuur, E.A.G., Trucco, C., Hicks Pries, C.E., Crummer, K.G., and 913 Baron Lopez, A.F. (2011) Effects of experimental warming of air, soil and permafrost on carbon balance in Alaskan tundra. Glob. Chang. Biol. 17: 1394-

916 Nazaries, L., Murrell, J.C., Millard, P., Baggs, L., and Singh, B.K. (2013) Methane, 917 microbes and models: fundamental understanding of the soil methane cycle for 918 future predictions. Environ. Microbiol. 15: 2395-2417.

919 Nilsson, A. (2006) Limnological responses to late Holocene permafrost dynamics at 920 the Stordalen mire, Abisko, northern Sweden Examensarbeten i Geologi vid. Wiley-Blackwell and Society for Applied Microbiology 
$921 \quad$ Science (80-. ).

922 Nilsson, M. and Bohlin, E. (1993) Methane and carbon dioxide concentrations in 923 bogs and fens - with special reference to the effects of the botanical composition 924 of the peat. Br. Ecol. Soc. 81: 615-625.

925 O’Donnell, J.A., Jorgenson, M.T., Harden, J.W., McGuire, A.D., Kanevskiy, M.Z., and 926 Wickland, K.P. (2012) The Effects of Permafrost Thaw on Soil Hydrologic, 927 Thermal, and Carbon Dynamics in an Alaskan Peatland. Ecosystems 15: 213928229.

929 Olefeldt, D., Turetsky, M.R., Crill, P.M., and Mcguire, A.D. (2013) Environmental and 930 physical controls on northern terrestrial methane emissions across permafrost 931 zones. Glob. Chang. Biol. 19: 589-603.

932 Oren, A. (2014a) The Family Methanobacteriaceae. In, The Prokaryotes. Springer 933 Berlin Heidelberg, Berlin, Heidelberg, pp. 165-193.

934 Oren, A. (2014b) The Family Methanoregulaceae. In, The Prokaryotes. Springer 935 Berlin Heidelberg, Berlin, Heidelberg, pp. 253-258.

936 Oren, A. (2014c) The Family Methanosarcinaceae. In, The Prokaryotes. Springer 937 Berlin Heidelberg, Berlin, Heidelberg, pp. 259-281.

938 Osterkamp, T.E., Jorgenson, M.T., Schuur, E.A.G., Shur, Y.L., Kanevskiy, M.Z., and 939 Vogel, J.G. (2009) Physical and Ecological Changes Associated with Warming 940 Permafrost and Thermokarst in Interior Alaska. Permafr. Periglac. Process. 20: $941 \quad 235-256$.

942 Pankratov, T.A., Kirsanova, L.A., Kaparullina, E.N., Kevbrin, V. V., and Dedysh, S.N. 943 (2012) Telmatobacter bradus gen. nov., sp. nov., a cellulolytic facultative 944 anaerobe from subdivision 1 of the Acidobacteria, and emended description of 945 Acidobacterium capsulatum Kishimoto et al. 1991. Int. J. Syst. Evol. Microbiol. $946 \quad 62: 430-437$.

947 Parviainen, M. and Luoto, M. (2007) Climate envelopes of mire complex types in $948 \quad$ Fennoscandia. Geography 89: 137-151. 

aCC-BY-NC-ND 4.0 International license.

949 Paul, K., Nonoh, J.O., Mikulski, L., and Brune, A. (2012) "Methanoplasmatales,"

950 Thermoplasmatales-related archaea in termite guts and other environments, are 951 the seventh order of methanogens. Appl. Environ. Microbiol. 78: 8245-53.

952 Payette, S., Delwaide, A., Caccianiga, M., and Beauchemin, M. (2004) Accelerated 953 thawing of subarctic peatland permafrost over the last 50 years. Geophys. Res. $954 \quad$ Lett. 31: 1-4.

955 Price, M.N., Dehal, P.S., and Arkin, A.P. (2010) FastTree 2--approximately maximum$956 \quad$ likelihood trees for large alignments. PLoS One 5: e9490.

957 Putkinen, A., Larmola, T., Tuomivirta, T., Siljanen, H.M.P., Bodrossy, L., Tuittila, E.-S., 958 and Fritze, H. (2012) Water dispersal of methanotrophic bacteria maintains 959 functional methane oxidation in sphagnum mosses. Front. Microbiol. 3: 15.

960 Quast, C., Pruesse, E., Yilmaz, P., Gerken, J., Schweer, T., Yarza, P., et al. (2013) 961 The SILVA ribosomal RNA gene database project: improved data processing 962 and web-based tools. Nucleic Acids Res. 41: D590-6.

963 Quiroga, M.V., Valverde, A., Mataloni, G., and Cowan, D. (2015) Understanding 964 diversity patterns in bacterioplankton communities from a sub-Antarctic peatland. Environ. Microbiol. Rep. 1-7.

966 Railton, J.B. and Sparling, J.H. (1973) Preliminary studies on the ecology of palsa 967 mounds in northern Ontario. J. Bot. 51: 1037-1044.

968 Rundqvist, S., Hedenås, H., Sandström, A., Emanuelsson, U., Eriksson, H., 969 Jonasson, C., and Callaghan, T. V (2011) Tree and shrub expansion over the 970 past 34 years at the tree-line near Abisko, Sweden. Ambio 40: 683-92.

971 Rydén, B.E., Fors, L., and Kostov, L. (1980) Physical Properties of the Tundra Soil972 Water System at Stordalen, Abisko. Ecol. Bull. 30: 27-54.

973 Sakai, S., Conrad, R., Liesack, W., and Imachi, H. (2010) Methanocella arvoryzae 974 sp. nov., a hydrogenotrophic methanogen isolated from rice field soil. Int. J. $975 \quad$ Syst. Evol. Microbiol. 60: 2918-23.

976 Schuur, E.A.G., McGuire, A.D., Schädel, C., Grosse, G., Harden, J.W., Hayes, D.J., Wiley-Blackwell and Society for Applied Microbiology 
977 et al. (2015) Climate change and the permafrost carbon feedback. Nature 520:

$978 \quad 171-179$.

979 Seppälä, M. (2011) Synthesis of studies of palsa formation underlining the 980 importance of local environmental and physical characteristics. Quat. Res. 75: $981 \quad 366-370$.

982 Serkebaeva, Y.M., Kim, Y., Liesack, W., and Dedysh, S.N. (2013) Pyrosequencing983 Based Assessment of the Bacteria Diversity in Surface and Subsurface Peat 984 Layers of a Northern Wetland, with Focus on Poorly Studied Phyla and $985 \quad$ Candidate Divisions. PLoS One 8: e63994.

986 Shade, A., Peter, H., Allison, S.D., Baho, D.L., Berga, M., Bürgmann, H., et al. (2012) 987 Fundamentals of microbial community resistance and resilience. Front. $988 \quad$ Microbiol. 3: 417.

989 Shannon, C.E. and Weaver, W. (1949) A mathematical theory of communication $990 \quad$ University of Illinois Press, Urbana.

991 Sharp, C.E., den Camp, H.J.M.O., Tamas, I., and Dunfield, P.F. (2013) Unusual 992 Members of the PVC Superphylum: The Methanotrophic Verrucomicrobia 993 Genus "Methylacidiphilum.” In, Planctomycetes: Cell Structure, Origins and 994 Biology. Humana Press, Totowa, NJ, pp. 211-227.

995 Shur, Y.L. and Jorgenson, M.T. (2007) Patterns of Permafrost Formation and 996 Degradation in Relation to Climate and Ecosystems. Permafr. Periglac. Process. 997 18: 7-19.

998 Singh, B.K., Quince, C., Macdonald, C. a, Khachane, A., Thomas, N., Al-Soud, W.A., 999 et al. (2014) Loss of microbial diversity in soils is coincident with reductions in 1001 Smith, K.S. and Ingram-Smith, C. (2007) Methanosaeta, the forgotten methanogen? 1002 Sollid, J.L. and Sørbel, L. (1998) Palsa Bogs as a Climate Indicator: Examples from 1003 Dovrefjell, Southern Norway. Ambio 27: 287-291.

1004 Stackebrandt, E. (2014) The Family Acidimicrobiaceae. In, The Prokaryotes: Wiley-Blackwell and Society for Applied Microbiology 
1005 Actinobacteria., pp. 1-1061.

1006 Stegen, J.C., Lin, X., Fredrickson, J.K., Chen, X., Kennedy, D.W., Murray, C.J., et al. 1007 (2013) Quantifying community assembly processes and identifying features that 1008 impose them. ISME J. 7: 2069-2079.

1009 Stegen, J.J.C., Lin, X., Konopka, A.E.A., and Fredrickson, J.K.J. (2012) Stochastic 1010 and deterministic assembly processes in subsurface microbial communities. 1011 ISME J. 6: 1653-64.

1012 Turetsky, M.R., Wieder, R.K., Vitt, D.H., Evans, R.J., and Scott, K.D. (2007) The 1013 disappearance of relict permafrost in boreal north America: Effects on peatland 1014 carbon storage and fluxes. Glob. Chang. Biol. 13: 1922-1934.

1015 Tveit, A., Schwacke, R., Svenning, M.M., and Urich, T. (2013) Organic carbon 1016 transformations in high-Arctic peat soils: key functions and microorganisms. 1017 ISME J. 7: 299-311.

1018 Venail, P. a. and Vives, M.J. (2013) Phylogenetic distance and species richness 1019 interactively affect the productivity of bacterial communities. Ecology 94: 252910202536.

1021 Wagner, D. and Liebner, S. (2009) Global Warming and Carbon Dynamics in 1022 Permafrost Soils: Methane Production and Oxidation. In, Margesin,R. (ed), Soil 1023 Biology, Soil Biology. Springer, Berlin, pp. 219-236.

1024 Ward, N.L., Challacombe, J.F., Janssen, P.H., Henrissat, B., Coutinho, P.M., Wu, M., 1025 et al. (2009) Three genomes from the phylum Acidobacteria provide insight into 1026 the lifestyles of these microorganisms in soils. Appl. Environ. Microbiol. 75: $1027 \quad 2046-56$.

1028 Webb, C.O., Ackerly, D.D., McPeek, M.A., and Donoghue, M.J. (2002) 1029 PHYLOGENIES AND COMMUNITY ECOLOGY. Annu. Rev. Ecol. Syst. 33: $1030 \quad 475-505$.

1031 Weiss, S., Van Treuren, W., Lozupone, C., Faust, K., Friedman, J., Deng, Y., et al. 1032 (2016) Correlation detection strategies in microbial data sets vary widely in Wiley-Blackwell and Society for Applied Microbiology 
bioRxiv preprint doi: https://doi.org/10.1101/143578; this version posted May 29, 2017. The copyright holder for this preprint (which was not

certified by peer review) is the author/funder, who has granted bioRxiv a license to display the preprint in perpetuity. It is made available uRage $\mathbf{3 8}$ of $\mathbf{4 3}$ aCC-BY-NC-ND 4.0 International license.

1033 sensitivity and precision. Isme $\mathrm{J}$ 1-13.

1034 Werner, J.J., Knights, D., Garcia, M.L., Scalfone, N.B., Smith, S., Yarasheski, K., et 1035 al. (2011) Bacterial community structures are unique and resilient in full-scale 1036 bioenergy systems. Proc. Natl. Acad. Sci. U. S. A. 108: 4158-63.

1037 Whitfeld, T.J.S., Kress, W.J., Erickson, D.L., and Weiblen, G.D. (2012) Change in 1038 community phylogenetic structure during tropical forest succession: evidence 1039 from New Guinea. Ecography (Cop.). 35: 821-830.

1040 Yang, S.J., Kang, I., and Cho, J.C. (2016) Expansion of Cultured Bacterial Diversity 1041 by Large-Scale Dilution-to-Extinction Culturing from a Single Seawater Sample. $1042 \quad$ Microb. Ecol. 71: 29-43.

1043 Yavitt, J.B., Yashiro, E., Cadillo-Quiroz, H., and Zinder, S.H. (2011) Methanogen 1044 diversity and community composition in peatlands of the central to northern 1045 Appalachian Mountain region, North America. Biogeochemistry 109: 117-131.

1046 Zoltai, S.C. (1993) Cyclic Development of Permafrost in the Peatlands of $1047 \quad$ Northwestern Canada. Arct. Alp. Res. 25: 240-246. 


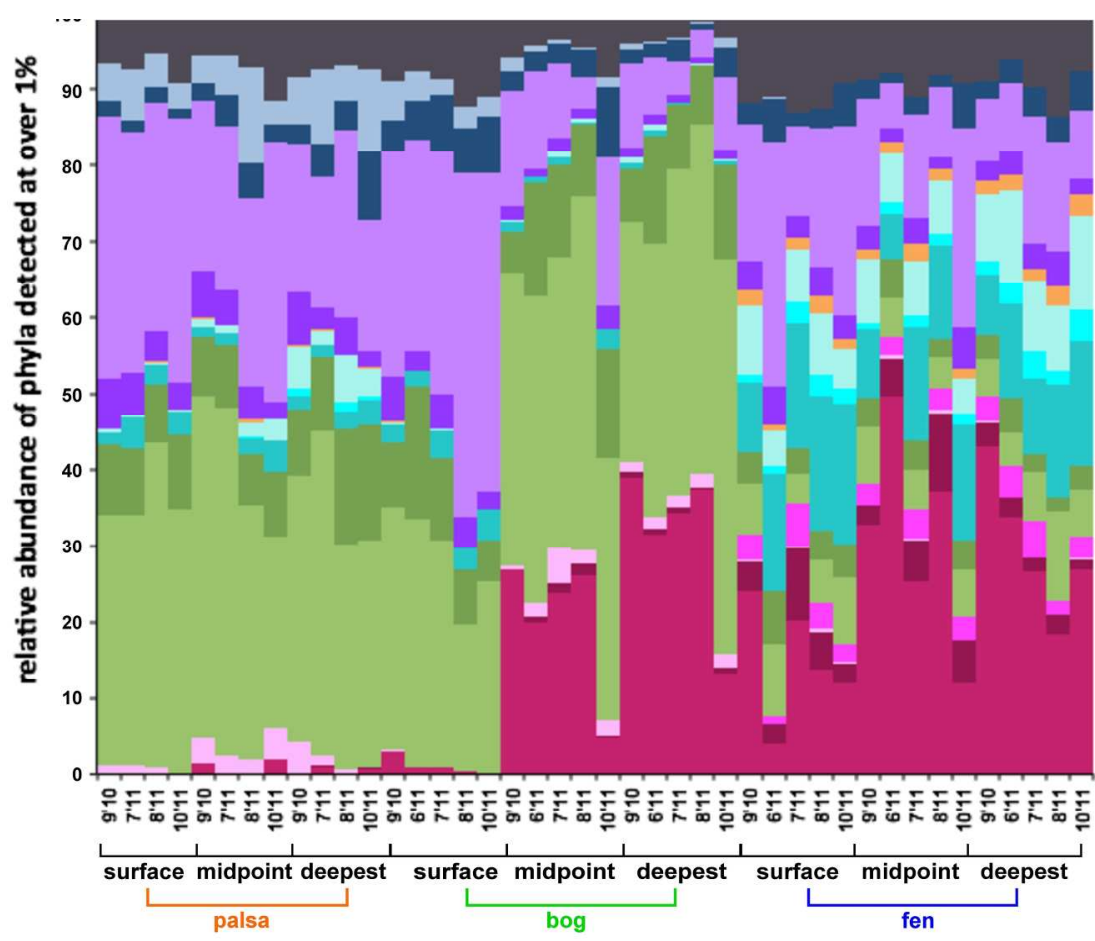

Dother

B: WD272 (WPS:

B: Verrucomicro.

B: Proteobacteri

B: Planctomycet

B. Microgenoma

B: Chloroflexi

B: Chlorobi

B: Bacteroidetes

B: Actinobacteri

B: Acidobacteria

A: Woesearchae

A: Thaumarchae

A: Bathyarchaeo

A: Euryarchaeot.

Fig 1 Mean relative abundance of phyla present at over $1 \%$. Samples grouped by site, then depth, then date. Date is marked along the horizontal axis as m'yy.

$210 \times 148 \mathrm{~mm}(300 \times 300 \mathrm{DPI})$ 
bioRxiv preprint doi: https://doi.org/10.1101/143578; this version posted May 29, 2017. The copyright holder for this preprint (which was not
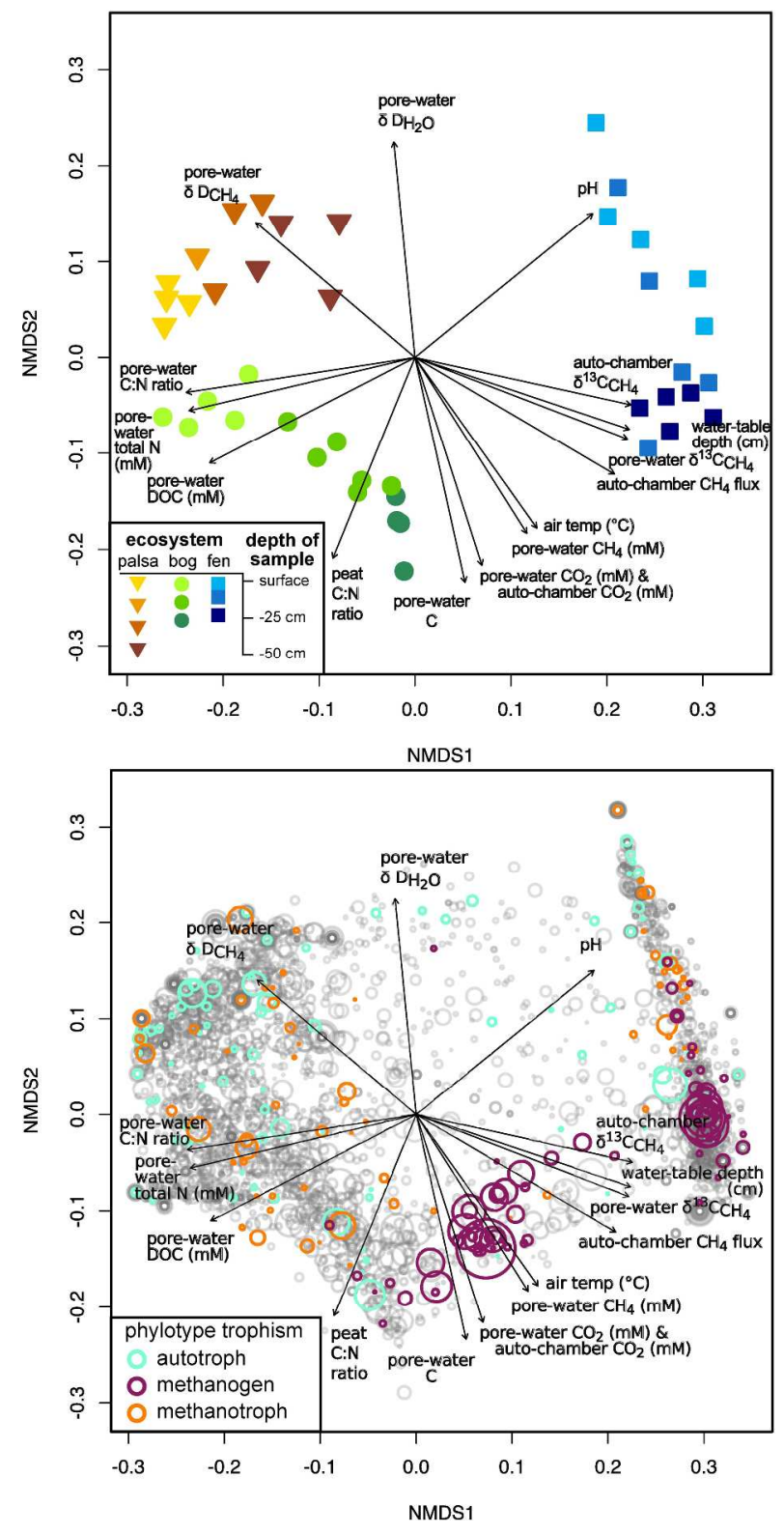

Fig 2 NMDS analysis of sample dissimilarity in community phylotype space, and environmental correlates (Stress $=0.0818, r 2=0.993$ ). a) The clustering of sites based on their community composition; sites are distinguished by shape and colored to show depth of sample; b) The relative positional contribution of phylotypes to this clustering, with phylotypes plotted as circles with diameter scaled to the log of the mean abundance, and colored to show putative C-cycle metabolism. Plotted vectors on a) \& b) are measured environmental variables that had significant correlation to differences in assemblage composition ( $p<0.01)$, with the terminal arrow indicating the direction of strongest change without reference to sign $(+$ or -$)$.

$285 \times 572 \mathrm{~mm}(300 \times 300 \mathrm{DPI})$ 

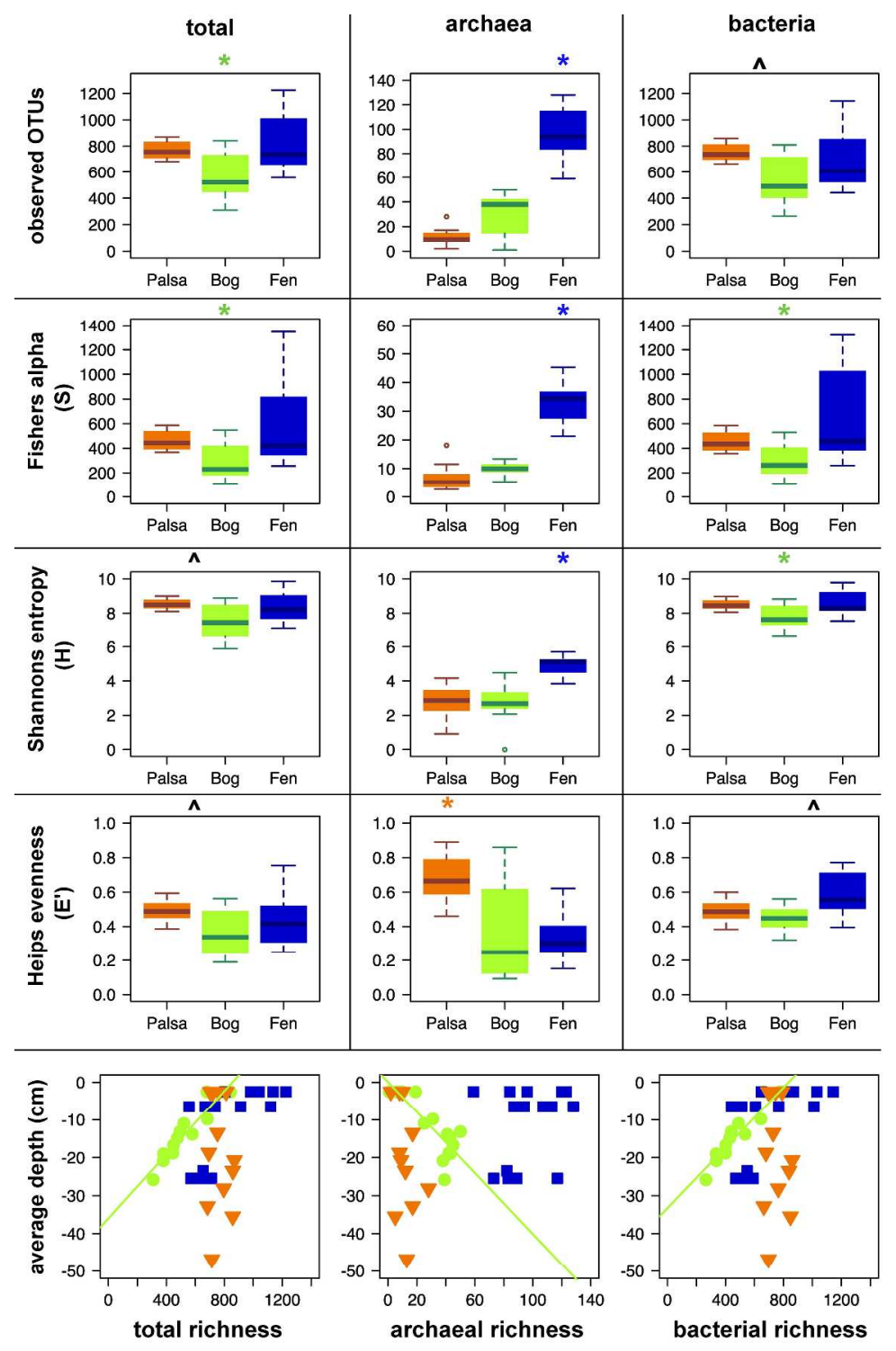

palsa

bog

fen

Fig 3 By-site comparison of alpha diversity metrics. a) The distribution of observed richness (top), Fisher's alpha-S (2nd from top), Shannon's entropy-H (2nd from bottom), Heip's evenness (bottom), on all $97 \%$ OTUs (left), archaeal OTUs (middle) and bacterial OTUs (right) in combined normalized $(\mathrm{N}=2000)$ samples. Significant differences were measured by Kruskal-Wallis post-hoc test $(* p<0.001$, where $*$ designates a site significantly different from the other two sites and $\wedge$ designates a significant difference between the two adjacent sites only)). b) The distribution of OTU richness with sample depth for all OTUs (left), archaeal OTUs (centre), bacterial OTUs (right). Green trend lines show the correlations between richness and depth of sample in the bog site.

$301 \times 488 \mathrm{~mm}(300 \times 300 \mathrm{DPI})$ 

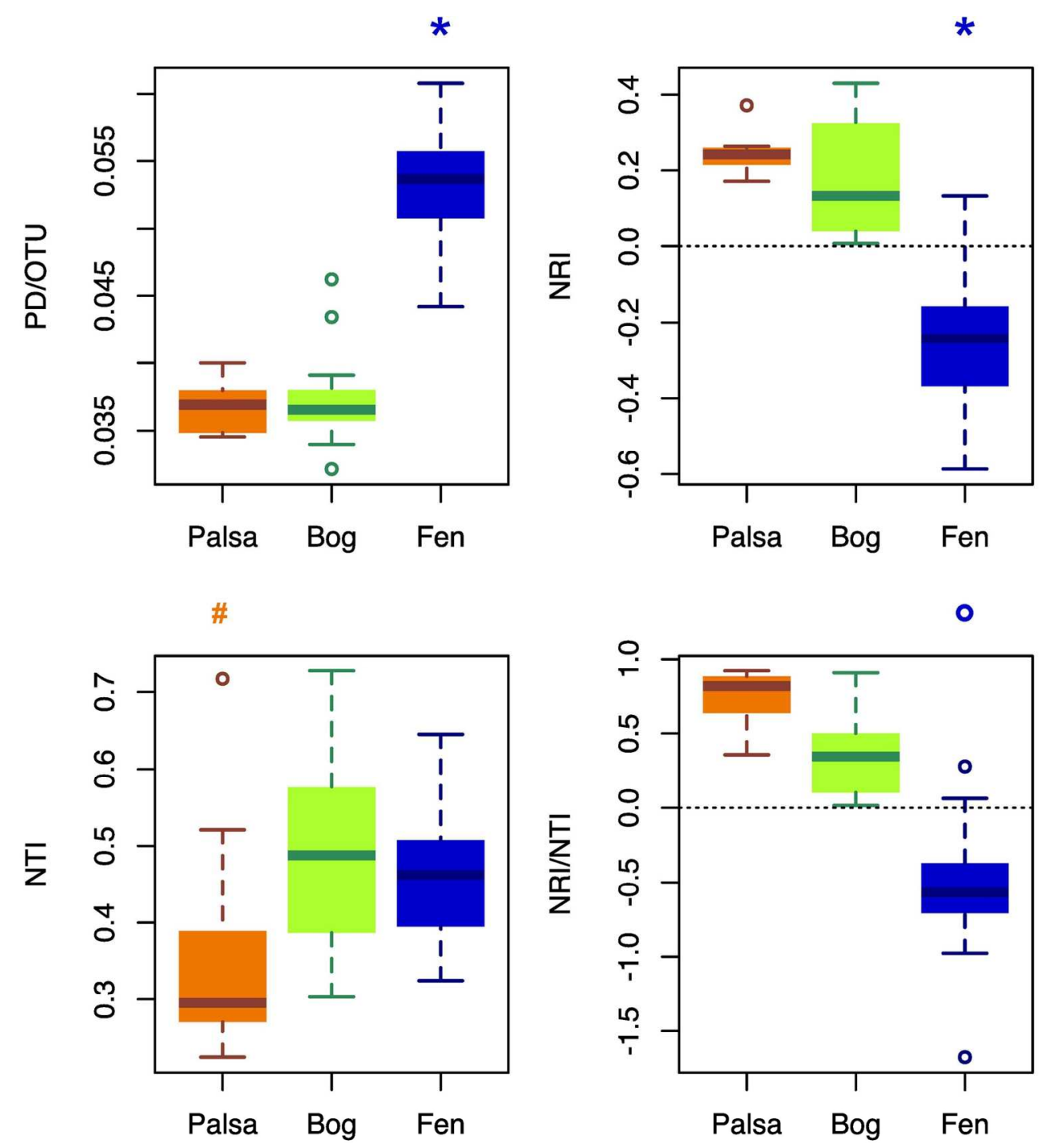

Fig 4 By-site comparison of phylogenetic diversity. topleft: faiths phylogenetic distance per OTU (PD/OTU); bottom left: Nearest taxon index (NTI); top right: Net relatedness Index (NRI), bottom right: NRI/NTI ratio.

$$
147 \times 167 \mathrm{~mm}(300 \times 300 \mathrm{DPI})
$$


bioRxiv preprint doi: https://doi.org/10.1101/143578; this version posted May 29, 2017. The copyright holder for this preprint (which was not

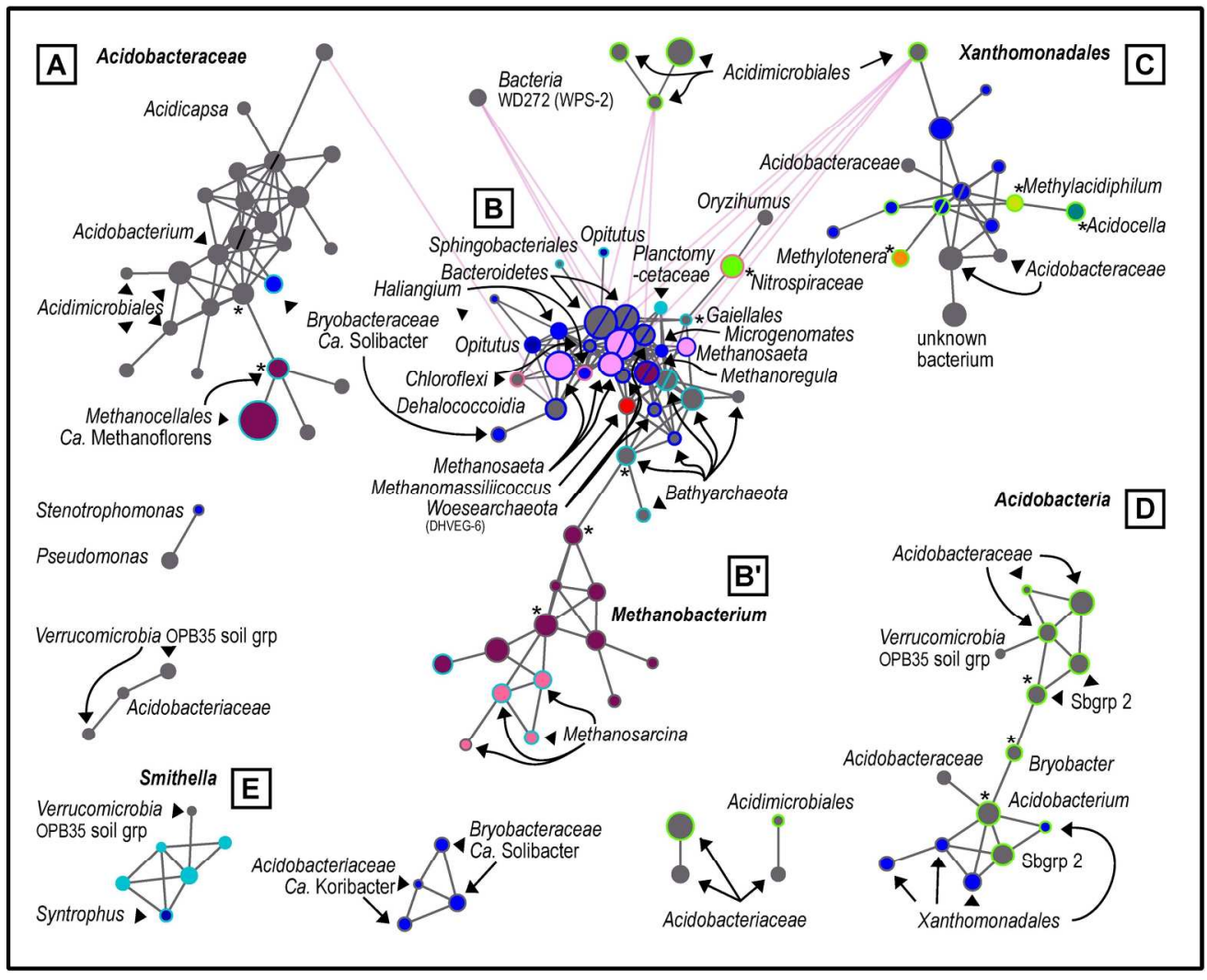

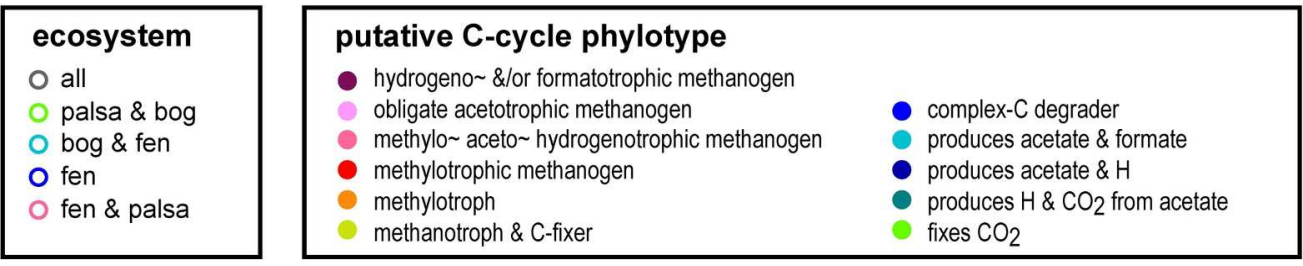

Fig 5 Network of phylotypes present in at least 15 samples with significant pairwise correlation. Circles indicate individual OTUs; circle diameter is a function of the log of the mean abundance. Circle colour denotes phylogenetically-inferred metabolism, and the colour of the outline denotes ecosystem presence. Circles with * are putative keystones and those with a / across the middle are putative hubs. Grey edges indicate co-occurrence, while pink edges indicate mutual-exclusion.

$$
181 \times 184 \mathrm{~mm}(300 \times 300 \mathrm{DPI})
$$

